\title{
Bacterial production in subarctic peatland lakes enriched by thawing permafrost
}

\author{
Bethany N. Deshpande, Sophie Crevecoeur, Alex Matveev, and Warwick F. Vincent \\ Centre for Northern Studies (CEN), Biology Department and Takuvik Joint International Laboratory, \\ Université Laval, Québec, QC, Canada \\ Correspondence to: Bethany N. Deshpande (bethanydeshpande@gmail.com)
}

Received: 31 January 2016 - Published in Biogeosciences Discuss.: 11 February 2016

Revised: 10 June 2016 - Accepted: 28 June 2016 - Published: 8 August 2016

\begin{abstract}
Peatlands extend over vast areas of the northern landscape. Within some of these areas, lakes and ponds are changing in size as a result of permafrost thawing and erosion, resulting in mobilization of the carbon-rich peatland soils. Our aims in the present study were to characterize the particle, carbon and nutrient regime of a set of thermokarst (thaw) lakes and their adjacent peatland permafrost soils in a rapidly degrading landscape in subarctic Québec, Canada, and by way of fluorescence microscopy, flow cytometry, production measurements and an in situ enrichment experiment, determine the bacterial characteristics of these waters relative to other thaw lakes and rock-basin lakes in the region. The soil active layer in a degrading palsa (peatland permafrost mound) adjacent to one of the lakes contained an elevated carbon content ( $51 \%$ of dry weight), high $\mathrm{C}: \mathrm{N}$ ratios (17: 1 by mass), and large stocks of other elements including $\mathrm{N}$ (3\% of dry weight), $\mathrm{Fe}(0.6 \%), \mathrm{S}(0.5 \%), \mathrm{Ca}(0.5 \%)$ and $\mathrm{P}$ $(0.05 \%)$. Two permafrost cores were obtained to a depth of $2.77 \mathrm{~m}$ in the palsa, and computerized tomography scans of the cores confirmed that they contained high concentrations $(>80 \%$ ) of ice. Upon thawing, the cores released nitrate and dissolved organic carbon (from all core depths sampled), and soluble reactive phosphorus (from bottom depths), at concentrations well above those in the adjacent lake waters. The active layer soil showed a range of particle sizes with a peak at $229 \mu \mathrm{m}$, and this was similar to the distribution of particles in the upper permafrost cores. The particle spectrum for the lake water overlapped with those for the soil, but extended to larger (surface water) or finer (bottom water) particles. On average, more than $50 \%$ of the bacterial cells and bacterial production was associated with particles $>3 \mu \mathrm{m}$. This relatively low contribution of free-living cells (operationally
\end{abstract}

defined as the $<1 \mu \mathrm{m}$ fraction) to bacterial production was a general feature of all of the northern lakes sampled, including other thaw lakes and shallow rock-basin lakes (average $\pm \mathrm{SE}$ of $25 \pm 6 \%$ ). However, a distinguishing feature of the peatland thaw lakes was significantly higher bacterial specific growth rates, which averaged 4 to 7 times higher values than in the other lake types. The in situ enrichment experiment showed no difference between organic carbon or phosphorus enrichment treatments at day 5 relative to the control, however there was an apparent increase in bacterial growth rates between days 1 and 5 in the soil and the carbon plus phosphorus enrichments. Collectively these results indicate that particles, nutrients and carbon are released by degrading permafrost peatland soils into their associated thermokarst lakes, creating favorable conditions for production by particle-based as well as free-living aquatic bacterial communities. The reduced bacterial concentrations despite high cellular growth rates imply that there is control of their population size by loss-related factors such as grazing and viral lysis.

\section{Introduction}

Aquatic environments in permafrost landscapes are biogeochemical hotspots that provide microbial communities with access to substrates that have been previously locked in frozen soils for centuries to millennia (Kling et al., 1991; Vonk et al., 2015). The highest soil organic carbon contents of the permafrost environment are found in areas of sporadic or isolated permafrost peatland, which span more than $5 \times 10^{5} \mathrm{~km}^{2}$ of land in the circumpolar North (Tarnocai et al., 
2009). The availability of organic substrates from these vast permafrost peatland environments to bacterial communities in aquatic ecosystems is likely to be influenced by a variety of factors, including the soil biogeochemical composition, particle and molecular size, and potentially other environmental factors, such as nutrient concentrations and temperature (Mann et al., 2014; Lapierre et al., 2013). Lakes in the boreal zone with flat catchments dominated by forest and peatland areas are strongly heterotrophic systems that have high rates of bacterial production (e.g., Kankaala et al., 2006), but less is known about the bacterial characteristics of peatland lakes further northwards, in permafrost regions.

Decomposition processes in aquatic ecosystems are mediated by bacterial communities that can be separated into two ecological groups: (1) free-living bacteria, in which solitary cells are suspended in the medium and break down dissolved organic matter; and (2) particle-attached bacteria, in which the communities are associated with various size-fractions of particles and break down this particulate organic material, as well as accessing dissolved materials (Kirchman and Mitchell, 1982; Vallières et al., 2008). In both cases, these activities result in consumption of oxygen, production of carbon dioxide, and the mineralization of organic materials.

In most lake and ocean environments, free-living bacteria dominate the total bacterial community in terms of numerical abundance (Unanue et al., 1992; Kirchman and Mitchell, 1982; Simon et al., 1990; Lami et al., 2009). However, there are many environments in which particle-based bacteria play a major role. Several studies from estuarine- and marinewaters show that particle-attached populations can account for 10 to 100 times more bacterial cells and activity than freeliving bacteria, depending on particle concentrations (Crump et al., 1999; Ghiglione et al., 2007; Acinas et al., 1999; Lami et al., 2009). A study of seven freshwater ecosystems including two marsh-systems showed that a small proportion of particle-attached bacteria $(<10 \%)$ was associated with $>40 \%$ of the bacterial community activity, and it was hypothesized that lake size may influence the presence of particulate matter for colonization via interactions between sediments and the water column (Kirchman and Mitchell, 1982). In the turbid waters of the Mackenzie River, which are strongly influenced by permafrost as well as fluvial erosion, more than $90 \%$ of the total bacterial production was associated with particles $>3 \mu \mathrm{m}$ (Vallières et al., 2008). Similarly, in the coastal waters of the Beaufort Sea, the $>3 \mu \mathrm{m}$ sizefraction often accounted for $>50 \%$ of total bacterial production (Garneau et al., 2006; Galand et al., 2008). Other research has identified that a dominant portion $(>50 \%)$ of bacterial cells were attached to particles (Masin et al., 2012), especially in turbid systems with high concentrations of particulate organic matter (Fletcher 1991; Lami et al., 2009).

Particle localization of microbial processes has wideranging implications for trophic processes in the water column and material fluxes to the sediments. In the oceanographic literature, large particles are referred to as "marine snow", and many studies that have shown the importance of these aggregates for food-web dynamics (Michaels and Silver, 1988; Alldredge and Silver, 1988; Kiørboe, 2001). Similarly, there has been attention given to "lake snow", although lake particulate matter is likely to be more of terrestrial origin, and therefore of different chemical composition than marine snow. Grossart and Simon (1993) found lake particle aggregates to be densely colonized by bacteria, with approximately $10^{8}$ bacterial cells per mL, 100 times higher than concentrations in the bulk water. The presence of particleattached bacteria may also result in greater community diversity, as has been demonstrated in studies of estuarine mixing zones (Crump et al., 1998; Waidner and Kirchman, 2007). A study by Ploug and Grossart (2000) identified a positive correlation between bacterial production, particulate organic carbon and aggregate size. Size also affects sinking velocities through Stokes' Law, and therefore the flux rates for transfer of materials from the pelagic zone to the sediments (Ploug and Grossart, 2000).

Permafrost thaw lakes are rich in suspended particulate material as a result of permafrost erosion (Breton et al., 2009; Watanabe et al., 2011). They are also continuously supplied with organic and inorganic inputs from the thermokarst processes in their surrounding catchments (Vonk et al., 2015), and there is increasing attention to the bacterial responses to such inputs. In the Mackenzie River Delta region, a mesocosm assay showed decreased planktonic bacterial production rates in response to permafrost soil enrichment, but a strong increase in benthic bacterial production rates (Moquin and Wrona, 2015). In a set of subarctic thermokarst ponds, late winter bacterial production was low and dominated by free-living bacterioplankton, while much higher production rates in summer were dominated by particle-attached bacteria, correlated with terrestrial carbon concentrations (Roiha et al., 2015). Permafrost peatland lakes are known to be strong emitters of greenhouse gases with diverse microbiota (Liebner et al., 2015), but little is known about the controls on their bacterial populations and productivity.

Our first aim in the present study was to investigate the physical and geochemical properties of permafrost peatland soils in order to better understand the allochthonous carbon, nutrient and particle inputs to peatland thermokarst lakes and their potential effects on bacterial activity. Secondly, we aimed to determine the distribution of bacterial production between the suspended and free-living size fractions in these peatland lakes enriched with particles from eroding permafrost. Our final aim was to experimentally determine the responses of peatland lake bacteria to permafrost soil inputs. Two hypotheses were evaluated: firstly, that particle-attached bacteria account for the dominant (>50\%) fraction of the total microbial activity, and secondly that organic carbon and nutrients originating from the erosion of permafrost soils promote bacterial metabolic activity and cellular growth. We undertook this research in subarctic Québec and first determined the chemical composition of the soil active layer and 
underlying permafrost in a palsa (organic permafrost mound) that was adjacent to and eroding into a peatland thaw lake. We examined the distribution of soil particle sizes and compared these with particle distributions in permafrost peatland lakes, with comparisons of particle size spectra, nutrients and organic carbon with other types of lakes in the region. We then measured bacterial abundance (BA) and production rates (BP) associated with different size fractions in the peatland lakes and others, and tested the effects of phosphorus, carbon and soil enrichment on bacterial concentrations and activity by way of an in situ incubation experiment.

\section{Materials and methods}

\subsection{Study sites}

The primary sampling sites were near Kuujjuarapik-

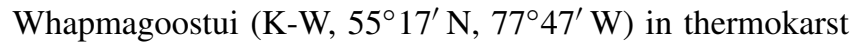
lakes and their surrounding soils in the peatland palsa valley of the Sasapimakwananistikw River (SAS; Fig. 1). Additional sampling for comparison took place in thermokarst lakes in the mineral lithalsa (mineral permafrost mounds) valley of the Kwakwatanikapistikw River (KWK) near K-W; glaciated rock-basin lakes, also near K-W, but not influenced by permafrost (RBL); and lithalsa lakes up to $200 \mathrm{~km}$ further to the North (SEC, BGR, NAS). This coastal region of northern Québec has experienced rapid climate change, including an increase in mean annual temperatures from $-4.2^{\circ} \mathrm{C}$ for $1932-1960$ to $-2.6 \pm 1.2^{\circ} \mathrm{C}$ for $2001-2010$, accompanied by changes in the permafrost landscapes, including expansion of the tree line, changes to snow conditions, and various changes in thermokarst lakes frequency and extent (Bhiry et al., 2011). A total of 15 lakes were sampled at five permafrost-affected sites and one non-permafrost-affected area (Fig. 1; detailed location and depth information is given in Table S1 in the Supplement).

The SAS valley is an area of sporadic permafrost $(<2 \%$ frozen ground) mainly colonized by Sphagnum and Carex, with dark brown and black colored thermokarst lakes (ArlenPouliot and Bhiry, 2005; Fillion et al., 2014). This peat bog contains more than 50 isolated permafrost mounds (palsas; Fig. 2) covered by a $60 \mathrm{~cm}$ soil active layer (Arlen-Pouliot and Bhiry, 2005; Fillion et al., 2014). Two sets of lakes were sampled in the SAS valley: the SAS1 set of lakes was located to the south and the SAS2 lakes were located to the north of the river. The SAS lakes are stratified, heterotrophic lakes with anoxic zones throughout the majority of the water column, and surface waters that are under-saturated in oxygen (Deshpande et al., 2015). These lakes have abundant and active methanotrophic bacterial communities indicating their high methane supply rates (Crevecoeur et al., 2015), and they emit greenhouse gases to the atmosphere at flux rates up to $13 \mathrm{mmol} \mathrm{CH}_{4} \mathrm{~m}^{-2} \mathrm{~d}^{-1}$ and $240 \mathrm{mmol} \mathrm{CO}_{2} \mathrm{~m}^{-2} \mathrm{~d}^{-1}$ (Matveev et al., 2016).

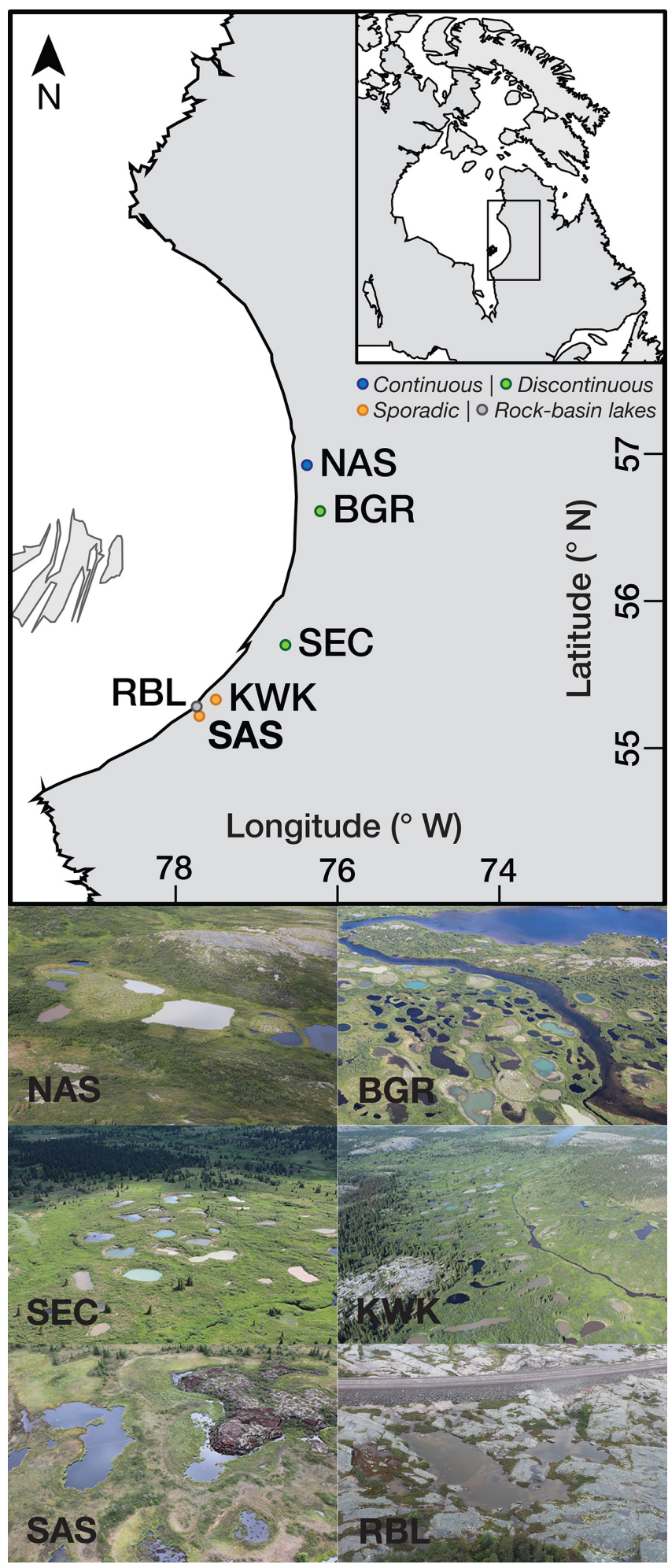

Figure 1. Map of the study region and photos of the six study areas.

The valley of the Kwakwatanikapistikw River (KWK) is also in an area of sporadic permafrost, located only $8 \mathrm{~km}$ from SAS. It is colonized by lichen-moss, shrub- 


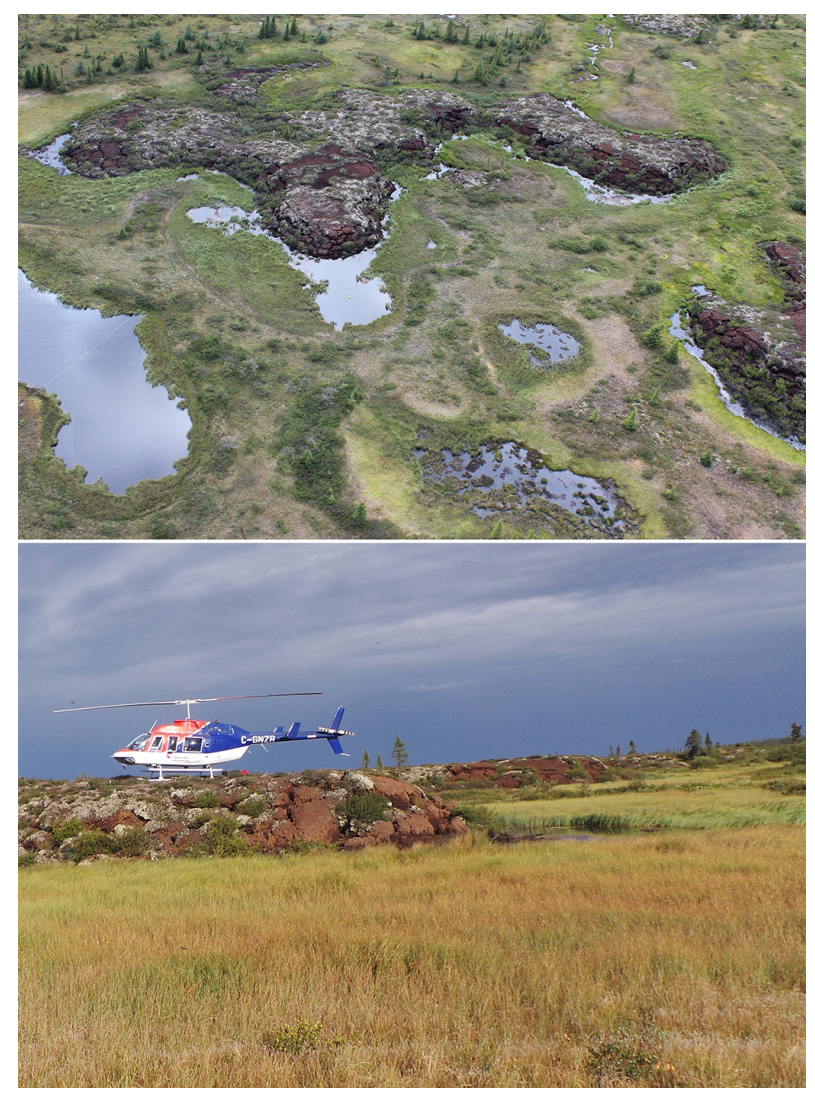

Figure 2. Palsas and their associated thermokarst lakes in the SAS valley. Upper panel: aerial view of the SAS1 area; lower panel ground-level view of SAS1B (photograph by Alexander Culley).

tundra vegetation, and forest patches in wind-sheltered areas (Arlen-Pouliot and Bhiry, 2005), and contains numerous thermokarst lakes that vary in color from blue-green to brown. The SEC site $\left(55^{\circ} 42.067^{\prime} \mathrm{N}, 76^{\circ} 38.604^{\prime} \mathrm{W}\right)$ was located $86.0 \mathrm{~km}$ northeast of $\mathrm{K}-\mathrm{W}$ and the BGR site was located near the Hudson Bay and the village of Umijuaq $\left(56^{\circ} 36.63^{\prime} \mathrm{N}, 76^{\circ} 12.85^{\prime} \mathrm{W}\right)$, both in areas of discontinuous permafrost. BGR1 appears to be a rapidly expanding lake, with a maximum depth of $3.2 \mathrm{~m}$ in 2006 (Breton et al., 2009) that had increased to $4.0 \mathrm{~m}$ in 2013 (Deshpande et al., 2015), and $4.2 \mathrm{~m}$ in the present study. The Nastapoka River valley (NAS) contains thermokarst lakes that were formed by thawing lithalsa mounds in this region of continuous permafrost. The non-permafrost-affected, rock-basin lakes (RBL) in the $\mathrm{K}-\mathrm{W}$ region are of similar area and shallow depth $(0.8-2.1 \mathrm{~m})$ to the thermokarst systems, but with rock substrate catchments rather than permafrost soils.

\subsection{Lake sampling and profiling}

Sampling took place during three consecutive summers from 2012-2014. At each visit, surface water was sampled using sterile plastic containers. A Van Dorn sampler was used to retrieve samples from the oxycline or the bottom waters, $0.2 \mathrm{~m}$ above the bottom sediments. Water samples were analyzed for soluble reactive phosphorus (SRP; detection limit of $0.5 \mu \mathrm{g} \mathrm{PL}^{-1}$ ), total nitrogen (TN; detection limit of $0.008 \mathrm{mg} \mathrm{N} \mathrm{L}^{-1}$ ), dissolved organic carbon (DOC; detection limit of $\left.0.05 \mathrm{mg} \mathrm{DOC} \mathrm{L}^{-1}\right)$, Chlorophyll $a(\mathrm{Chl} a)$, and total suspended solids (TSS) according to methods in Laurion et al. (2010). Ammonium and nitrate (including nitrite) concentrations were measured in water from the SAS valley only using a Lachat AutoAnalyzer (detection limit of $10 \mu \mathrm{g}$ $\mathrm{NL}^{-1}$ ). Soil was sampled from the active layer directly next to a lake at each site and stored in sterile plastic bags. Frozen samples of both water and soils were returned to Université Laval (Laboratoire de géomorphologie et de sédimentologie, FFGG) to determine particle size distribution via Laser Particle Size Analyzer (LA-950V2, Horiba Ltd., Japan).

For CDOM (colored dissolved organic matter) analysis, water samples from the surface waters of the SAS lakes were filtered through sample-rinsed $47 \mathrm{~mm}, 0.2 \mu \mathrm{m}$ pore size cellulose acetate membrane filters and the filtrate was analyzed with the Varian Cary 100 UV-VIS spectrophotometer. The absorbance scans were obtained from the spectrophotometer over the wavelength range of $200-850 \mathrm{~nm}$ at natural $\mathrm{pH}$ using a $1 \mathrm{~cm}$ acid-cleaned quartz cuvette on dual beam mode, at a speed of $240 \mathrm{~nm} \mathrm{~min}^{-1}$ with a slit width of $1 \mathrm{~nm}$. The absorbance was measured against ultra-pure water and corrected against the blanks prepared on site. Absorption coefficients were calculated as $a(\lambda)=2.303 \times A(\lambda) / L$, where $a(\lambda)$ is the absorption coefficient at a wavelength $\lambda$, $A(\lambda)$ is the optical density (absorbance) for wavelength $\lambda$, and $L$ is the path length of the cuvette $(\mathrm{m})$. Absorption slope parameters were also determined from absorbance at $275 \mathrm{~nm}\left(a_{275}\right)$ and $295 \mathrm{~nm}\left(a_{295}\right)$ using the formula $a_{295}=$ $a_{275} e^{-S(295-275)}$, where $S\left(\mathrm{~nm}^{-1}\right)$ is the absorption slope parameter (Fichot and Benner, 2012).

\subsection{Active layer and permafrost core sampling}

Triplicate soil samples were retrieved from the surface active layer of a palsa adjacent to lake SAS1B on 3 August 2013; the soil was sampled from half way up the face of the palsa (approximately $1 \mathrm{~m}$ above the lake surface) that was eroding and collapsing into the lake by pushing tubes with an internal diameter of $6 \mathrm{~cm}$ and a length of $20 \mathrm{~cm}$ horizontally into the palsa (Fig. 2). Subsamples were frozen and transported to Québec City for CHN (LECO analyzer, CEN, Québec) and other geochemical analyses (ICP-AES; INRS-ETE, Québec). Enrichment Factors (EF) for the soil samples were determined as per Gorham and Janssens (2005):

$\mathrm{EF}_{\text {soil }}=\left([x]_{\text {sample }} /[\mathrm{Al}]_{\text {sample }}\right) /\left([x]_{\text {soil }} /[\mathrm{Al}]_{\text {soil }}\right)$,

where $[x]_{\text {sample }}$ is the concentration of a given element, $x$, in the study sample, $[\mathrm{Al}]_{\text {sample }}$ is the concentration of the element $\mathrm{Al}$ in the study sample, $[x]_{\text {soil }}$ is the world median concentration of element $x$, and [Al $]_{\text {soil }}$ is the world median 
concentration of the element Al. Global average values were taken from Bowen (1979).

Permafrost cores were sampled from two sites $15 \mathrm{~m}$ apart on large an organic-rich palsa mound at the SAS2 site (Fig. 1) on 5 August 2013. For permafrost core sampling, a soil pit was dug into the palsa to the base of the active layer. The permafrost cores were then retrieved using a portable drill system (Calmels et al., 2005). The recovered cores were $10 \mathrm{~cm}$ in diameter, with lengths of 2.8 and $3.0 \mathrm{~m}$. Samples were returned to the Centre for Northern Studies (Université Laval, Québec) and maintained frozen. The frozen core was characterized by computerized tomography (CT) scanning (Calmels and Allard, 2004) and later subsampled. Subsamples were $1.5 \mathrm{~cm}$ thick and centered at depths of 1.25, 1.75, and $2.77 \mathrm{~m}$ from each of the two permafrost cores. Sample depths were chosen to span the full-length of the permafrost core, and based on CT-scan results. Each sub-sample was placed in a sterilized container filled with ultrapure Milli-Q water and thawed for a period of $48 \mathrm{~h}$. Samples were then lightly shaken and then filtered through $47 \mathrm{~mm}, 0.2 \mu \mathrm{m}$ pore size cellulose acetate membrane filter. The filtrate and a blank (Milli-Q water) were analysed for $\mathrm{DOC}, \mathrm{NO}_{3}^{-}$(including $\mathrm{NO}_{2}^{-}$) and SRP (INRS-ETE, Québec). DOC was analyzed using a Shimadzu 5000A TOC Analyzer (detection limits of $\left.0.05 \mathrm{mg} \mathrm{C} \mathrm{L}^{-1}\right)$. SRP and $\mathrm{NO}_{3}^{-}$were analyzed using a Lachat AutoAnalyzer (detection limit of $1 \mu \mathrm{g} \mathrm{N}$ and $\mathrm{PL}^{-1}$ ). DOC, $\mathrm{SRP}$, and $\mathrm{NO}_{3}^{-}$concentrations were normalized to per unit volume of ice in the sample, to determine the potential contributions from melted ice. CDOM was analyzed as described above. Unfiltered diluted samples were analyzed for particlesize distribution as described above. Additional subsamples from throughout the core were analysed for total $\mathrm{CHN}$ content (LECO analyzer, CEN).

\subsection{Size fractionation}

Surface water was sampled from the pelagic zones of lakes BGR1, SEC, KWK12, SAS2A, NAS1A and RBL4K for size fractionation. Phytoplankton and particle-attached bacterial communities were filtered through a $35 \mu \mathrm{m}$ Nitex screen. The bacteria were then further separated into two size fractions: either by passing through a glass fibre filter (Pall Canada Ltd.) with a nominal pore size of $3.0 \mu \mathrm{m}$, or by further filtration through a Whatman GF/B glass fibre filter with a nominal pore size of $1.0 \mu \mathrm{m}$. Approximately $2.0 \mathrm{~L}$ was filtered for each size fraction, and an unfiltered total community sample was also preserved for concurrent analysis.

\subsection{Bacterial abundance}

The bacterial communities in the size-fractionated samples and from the enrichment experiment were counted after staining with 4',6-diamidino-2-phenylindole (DAPI). Samples were preserved with formaldehyde $(3.7 \%$ final concentration) in pre-washed plastic bottles, pre-rinsed with the sample and stored at $4{ }^{\circ} \mathrm{C}$ for up to 6 months. Samples were later shaken to break up larger particles and then filtered onto Nuclepore black polycarbonate membranes $(0.22 \mu \mathrm{m}$, $25 \mathrm{~mm})$ placed on cellulose acetate backing filters $(0.7 \mu \mathrm{m}$, $25 \mathrm{~mm}$ ) under low pressure. DAPI was added to $1.5 \mathrm{~mL}$ of sample ( $4 \mu \mathrm{g} \mathrm{mL}^{-1}$ final concentration) and left to stain for 10 min before filtering until dry. Filters were mounted on slides with coverslips and non-fluorescent immersion oil, and stored at $-20^{\circ} \mathrm{C}$ until counting on a Zeiss Axioskip 2 epifluorescence microscope, under UV light and $1000 \times$ magnification with immersion oil. A minimum of 15 fields or 400 cells were counted for each sample triplicate.

All other bacterial samples were counted via flow cytometer (FACSCalibur, BD Biosciences Inc., USA) following the procedure described in Comte et al. (2016). Samples were fixed with glutaraldehyde (1\% final concentration) and stored at $-80^{\circ} \mathrm{C}$ until analysis. Bacterial samples were then shaken and a $500 \mu \mathrm{L}$ aliquot was stained with the nucleic acid dye 50X SYBR Green I $\left(20 \mu \mathrm{L} \mathrm{mL}^{-1}\right.$ final concentration; Life Technologies, Thermo Fisher Scientific, Waltham MA, USA) for $10 \mathrm{~min}$ in the dark, and processed at the lowest flow rate $\left(12 \mu \mathrm{L} \mathrm{min}^{-1}\right)$ using $1 \mu \mathrm{m}$ yellow-green microspheres (Polysciences Inc., Warrington PA, USA) solution as an internal standard. Bacterial cells were enumerated based on fluorescence (FL1) and side-scatter characteristics while excited at $488 \mathrm{~nm}$, with data analyzed using the CellQuest Pro software with manual gating.

\subsection{Bacterial production}

Bacterial production (BP) rates were measured via protein synthesis using radio-labeled leucine incorporation (Kirchman, 2001). Triplicate microfuge tubes plus a killed control each containing $1.5 \mathrm{~mL}$ of sample and $40 \mathrm{nM}$ of [4,5${ }^{3} \mathrm{H}$ ]leucine (60 $\mathrm{Ci} \mathrm{mmol}^{-1}$, PerkinElmer Inc.) were incubated for $1 \mathrm{~h}$ at $15^{\circ} \mathrm{C}$. After 1 hour, biomass production was halted by the addition of $100 \mu \mathrm{L}$ of trichloroacetic acid $(100 \%)$ and stored at $4^{\circ} \mathrm{C}$. Later, the samples were returned to the Takuvik radio-isotope laboratory at Université Laval. Samples were processed using the centrifugation method of Smith and Azam (1992) and then radio-assayed in a scintillation counter to measure the ${ }^{3} \mathrm{H}$-leucine uptake. Net bacterial $\mathrm{C}$ production was estimated using a conversion factor of $3.1 \mathrm{~kg} \mathrm{C}$ per mole of leucine (Kirchman et al., 1993; Iriberri et al., 1990). Bacterial community specific growth rates $\left(\mathrm{BG}, \mathrm{d}^{-1}\right.$ ) were determined (as described in Kirchman, 2001) via $\mathrm{BG}=\mathrm{BP} / \mathrm{B}$, where $\mathrm{BP}$ are bacterial production rates $\left(\mu \mathrm{g} \mathrm{CL}^{-1} \mathrm{~h}^{-1}\right.$ ), and $\mathrm{B}$ is the bacterial biomass (fg $\mathrm{C} \mathrm{mL}^{-1}$ ) that was converted from bacterial cellular counts (cells $\mathrm{mL}^{-1}$ ) to units of carbon using an average cellular carbon content of $18 \mathrm{fg} \mathrm{C}$ cell $^{-1}$, as measured in the nearby KWK lakes (Roiha et al., 2015). 


\subsection{Enrichment experiment}

At lake SAS1B, the following treatments were added to triplicate $20 \mathrm{~L}$ containers of lake water: $43 \mu \mathrm{mol} \mathrm{L}^{-1}$ of glucose (G; to achieve an estimated $20 \%$ increase of ambient DOC based on previous measurements), $1.8 \mu \mathrm{g} \mathrm{L}^{-1}$ of phosphorus (P; $10 \%$ enrichment of total $\mathrm{P}$ ), glucose and phosphorus together $(\mathrm{G}+\mathrm{P})$, and $6.2 \mathrm{mg} \mathrm{L}^{-1}$ of an aqueous suspension of the soil from the SAS1B palsa face, sampled and analyzed as described above ( $\mathrm{S}$; equivalent to $20 \%$ increase in total carbon relative to ambient DOC). A sample control was also prepared (C). Samples were taken immediately after enrichment $\left(t_{0}\right)$, and from each container after 5 days $\left(t_{5}\right)$ of incubation in situ in the near-surface waters of SAS1B. Chl $a$, BA and $\mathrm{BP}$ rates were measured in each treatment.

\subsection{Statistical analysis}

Statistical differences were examined between the SAS peatland lakes and the other study lakes. Environmental and bacterial variables for the comparison of lake waters were analysed by 1-way ANOVA for three lake groups: the SAS lakes, the other thermokarst lakes, and the non-thermokarst rockbasin lakes. A 2-way ANOVA was used to compare environmental and biological differences between surface and bottom waters of the lake groups mentioned above. For the size-fractionation data, a 2-way ANOVA was performed on pre-standardized variables, with the factors of lake and sizefraction following the Shapiro normality test. The enrichment experiment was analyzed via 2-factor repeated measures ANOVA, with each replicate individually tracked. Variables before and after enrichment were also compared via Holm-Sidak pairwise comparisons. BG were normalized by square root transformation, and BA was log transformed. Analyses were done using GraphPad Prism (v. 6.0f, GraphPad Software Inc., USA) and SigmaPlot (v. 12, Systat Software Inc., USA).

\section{Results}

\subsection{Active layer soil analyses}

The SAS active layer extended to $60 \mathrm{~cm}$ depth and contained $509 \mathrm{~g} \mathrm{~kg}^{-1}$ of carbon, or $50.9 \%$ of the soil by mass, and $30 \mathrm{~g} \mathrm{~kg}^{-1}$ of nitrogen (Table 1). Several elements were present in substantial concentrations, including phosphorus at a mean value $( \pm \mathrm{SD})$ of $545(19) \mathrm{mg} \mathrm{kg}^{-1}$, iron at 6.0 (1.6) $\mathrm{g} \mathrm{kg}^{-1}$, and calcium at $5.2(3.4) \mathrm{mg} \mathrm{kg}^{-1}$. The soil enrichment factors $(\mathrm{EF})$ were used to compare concentrations of soil elements with world medians (Bowen, 1979) to determine whether the elements were derived uniquely from wind-blown mineral soil ( $\mathrm{EF} \leq 1)$, or were more likely to accumulate due to multiple sources (EF $\gg 1)$ (Gorham and Janssens, 2005). Several elements had $\mathrm{EF}$ values $<1$, including $\mathrm{K}, \mathrm{Na}$, and $\mathrm{Mg}$. For $\mathrm{Al}, \mathrm{Mn}, \mathrm{Pb}, \mathrm{Cr}, \mathrm{Zn}$, and $\mathrm{Ba}$, the $\mathrm{EF}$ values were between 1 and 2. Phosphorus had an EF of 16, and $\mathrm{S}$ had the highest EF value of 132 .

\subsection{Permafrost core analysis and comparison with lake water}

The frozen permafrost cores were composed mainly of organic matter intercalated with ice $(>80 \%)$ in the two upper levels, with high concentrations of sediment only in the deepest level at $\sim 2.77 \mathrm{~m}$ (Fig. 3). The soils throughout the core released water containing nitrate and high concentrations of DOC, and the sediment-containing matter near the bottom of the cores additionally released SRP at concentrations up to 30 times those measured in the SAS lakes (Table 2).

The $a_{\mathrm{CDOM}}(\lambda)$ spectra for the DOC from the upper two permafrost core samples were almost identical, but differed as much as $185 \mathrm{~m}^{-1}$ from those for the bottom-core samples (Fig. S1). Mean values ( \pm SD) of $a_{\mathrm{CDOM}}(440)$ ranged from $9.96 \pm 0.28$ to $16.2 \pm 0.18 \mathrm{~m}^{-1}$ in all permafrost core samples except the bottom of core A, which was $51.5 \pm 0.4 \mathrm{~m}^{-1}$. The absorption slope parameter $\left(S_{275}-295\right)$ ranged from 0.0087 to $0.014 \mathrm{~nm}^{-1}$ in the permafrost cores (mean for all values of $0.0012 \pm 0.0018)$. For SAS lake water samples, $a_{\mathrm{CDOM}}(\lambda)$ spectra were similar to those observed from the permafrost core samples (Fig. S1); $a_{\mathrm{CDOM}}(440)$ ranged from $8.63 \pm 0.051$ to $18.1 \pm 0.068 \mathrm{~m}^{-1}$, and was consistently higher in bottom waters than in surface. Absorption slope parameters $\left(S_{275-295}\right)$ for the SAS water were within a notably smaller range than for the permafrost cores, and ranged from 0.011 to $0.012 \mathrm{~nm}^{-1}$ (mean for all values of $0.0115 \pm 0.0004)$.

\subsection{Particle size distribution in soils and lakes}

The particle-size distributions from the SAS permafrost cores followed a bimodal distribution as observed in the SAS active layer soil and the SAS lake water (Fig. 4). The maximum frequency of particle size (PSmax) ranged from 152 to $200 \mu \mathrm{m}$ for the permafrost layers at 1.25 and $1.75 \mathrm{~m}$ for both duplicates. The bottom layer of core A had a distribution maximum of $67 \mu \mathrm{m}$ while the maximum for core B was $51 \mu \mathrm{m}$. The active layer soil was similar to the distribution of particles in the upper permafrost cores, but with a maximum frequency at a slightly higher size $(229 \mu \mathrm{m})$, and an even distribution of particles from 80 to $300 \mu \mathrm{m}$. The particle spectrum for the SAS lake water overlapped with those for the soil, but the surface water spectrum extended to higher sizes and peaked at $394 \mu \mathrm{m}$, while the bottom water spectrum peaked at $200 \mu \mathrm{m}$ and extended to finer particles (Fig. 4).

As a further analysis of particle size distribution, difference spectra were calculated relative to the SAS2A surface waters for the active layer soil, upper permafrost soil and bottom waters. These curves emphasize the strong overlap in size spectra, with differences ranging from only -3 to $+6 \%$, depending on size class (Fig. 5). These curves also illustrate 
Table 1. Chemical properties of permafrost soil samples from the palsa surface at SAS1. Each value is the mean (standard deviation) of triplicates.

\begin{tabular}{lrlr}
\hline $\begin{array}{l}\text { Major } \\
\text { constituents }\end{array}$ & $\begin{array}{r}\text { Mean elemental } \\
\text { concentration (SD) } \\
\left(\mathrm{g} \mathrm{kg}^{-1} \text { dry weight }\right)\end{array}$ & $\begin{array}{l}\text { Minor } \\
\text { constituents }\end{array}$ & $\begin{array}{r}\text { Mean elemental } \\
\text { concentration (SD) } \\
\left(\mathrm{mg} \mathrm{kg}^{-1} \text { dry weight) }\right.\end{array}$ \\
\hline $\mathrm{C}$ & $509(10.9)$ & $\mathrm{Ba}$ & $43.5(10)$ \\
$\mathrm{N}$ & $30.0(2.6)$ & $\mathrm{Mn}$ & $24.5(12)$ \\
$\mathrm{Fe}$ & $6.04(1.6)$ & $\mathrm{Cu}$ & $6.5(1.1)$ \\
$\mathrm{Ca}$ & $5.23(3.4)$ & $\mathrm{Zn}$ & $5.8(0.5)$ \\
$\mathrm{S}$ & $4.86(0.52)$ & $\mathrm{Cr}$ & $5.8(0.5)$ \\
$\mathrm{Al}$ & $3.67(0.60)$ & $\mathrm{Ni}$ & $5.3(0.8)$ \\
$\mathrm{P}$ & $0.545(0.019)$ & $\mathrm{Mo}$ & $1.03(0.18)$ \\
$\mathrm{K}$ & $0.369(0.178)$ & $\mathrm{Pb}$ & $0.93(0.46)$ \\
$\mathrm{Na}$ & $0.344(0.123)$ & $\mathrm{Cd}$ & $0.12(0.04)$ \\
$\mathrm{Mg}$ & $0.339(0.189)$ & & \\
\hline
\end{tabular}

Table 2. Analysis from duplicate permafrost cores taken from palsas at the SAS2 study site. Gas, ice, and sediment (Sed) proportions (\%) are by volume. $a_{\mathrm{CDOM}}\left(\mathrm{m}^{-1}\right)$ is the CDOM absorption at $440 \mathrm{~nm}$. Dissolved organic carbon (DOC, in $\mathrm{mg} \mathrm{L}^{-1}$ ), soluble reactive phosphorus $\left(\mathrm{SRP}\right.$, in $\left.\mu \mathrm{g} \mathrm{L}^{-1}\right)$, and nitrate-nitrogen $\left(\mathrm{NO}_{3}\right.$, in $\mu \mathrm{g} \mathrm{N} \mathrm{L}^{-1}$ ) concentrations are potential contributions from melted core ice. N/A = sample was below detection limit.

\begin{tabular}{lrrrrrrrr}
\hline Core & Depth $(\mathrm{m})$ & Gas $(\%)$ & Ice $(\%)$ & Sed $(\%)$ & $a_{\text {CDOM }}$ & DOC & SRP & NO $_{3}$ \\
\hline A & 1.25 & 5 & 95 & 0 & 12.0 & 14.7 & N/A & 42.1 \\
& 1.75 & 18 & 82 & 0 & 13.3 & 13.9 & N/A & 36.5 \\
& 2.77 & 1 & 41 & 58 & 51.5 & 28.0 & 33.1 & 341 \\
\hline B & 1.25 & 3 & 97 & 0 & 16.2 & 26.9 & N/A & 62.2 \\
& 1.75 & 5 & 95 & 0 & 14.0 & 17.9 & N/A & 63.1 \\
& 2.77 & 2 & 53 & 44 & 10.0 & 28.8 & 20.8 & 93.6 \\
\hline
\end{tabular}
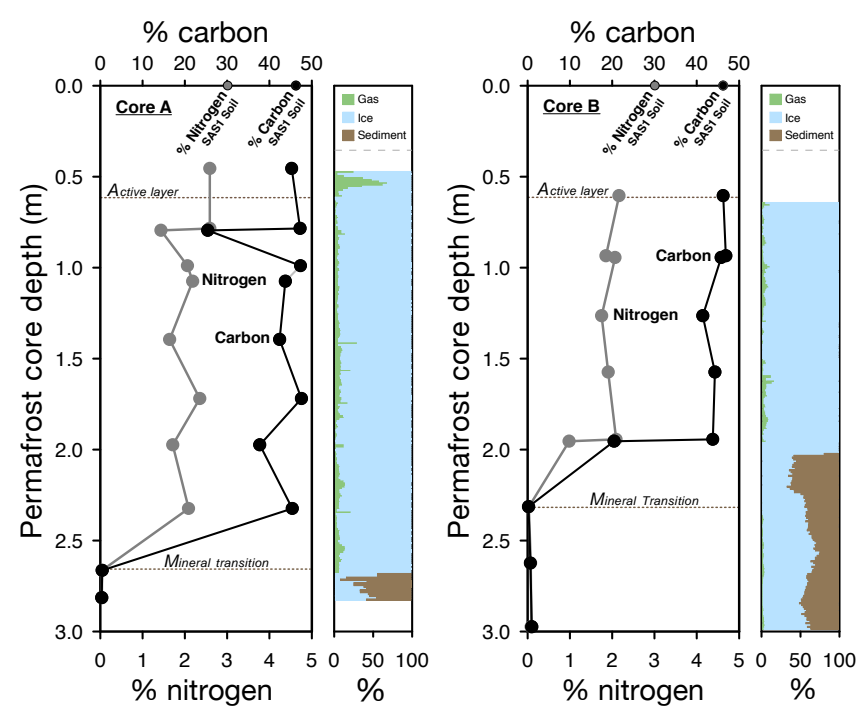

Figure 3. Percent carbon and nitrogen by dry weight in two permafrost cores from SAS palsa mounds, and proportions of gas, ice, and sediment by volume. how the surface water was slightly enriched in larger particles that ranged from 229 to $2010 \mu \mathrm{m}$ in diameter, while the bottom waters were enriched in finer particles that ranged from 39 to $200 \mu \mathrm{m}$.

Within-lake particle sizes showed highly variable distributions across the other lakes studied, with modes that ranged from 4 to $1337 \mu \mathrm{m}$ (Table 3; Fig. 4). The smallest particles were identified in RBL4K, a rock-basin lake unaffected by permafrost, with a mode particle size of $4 \mu \mathrm{m}$. Of the thaw lakes, the lakes from areas of sporadic, degrading permafrost had larger particles than the continuous- and discontinuouspermafrost lakes. For example, the mode particle sizes in NAS1A, BGR1, and SEC were 102,59 , and $153 \mu \mathrm{m}$, respectively. In contrast, the particle-size modes in SAS2A and KWK12 were 300 and $592 \mu \mathrm{m}$, respectively.

The concordance of particle distributions between the lake waters and their adjacent soils varied among the other sample sites (Fig. 4). The distribution of particles in KWK12 was strikingly similar to that of KWK active layer soil, while other lake samples tended to have modes that were higher than the mode observed in the soil, as in SAS. For example, the mode for BGR lake water was $59 \mu \mathrm{m}$, but $10 \mu \mathrm{m}$ for the adjacent mineral soil. As at SAS, the distribution of soil and 

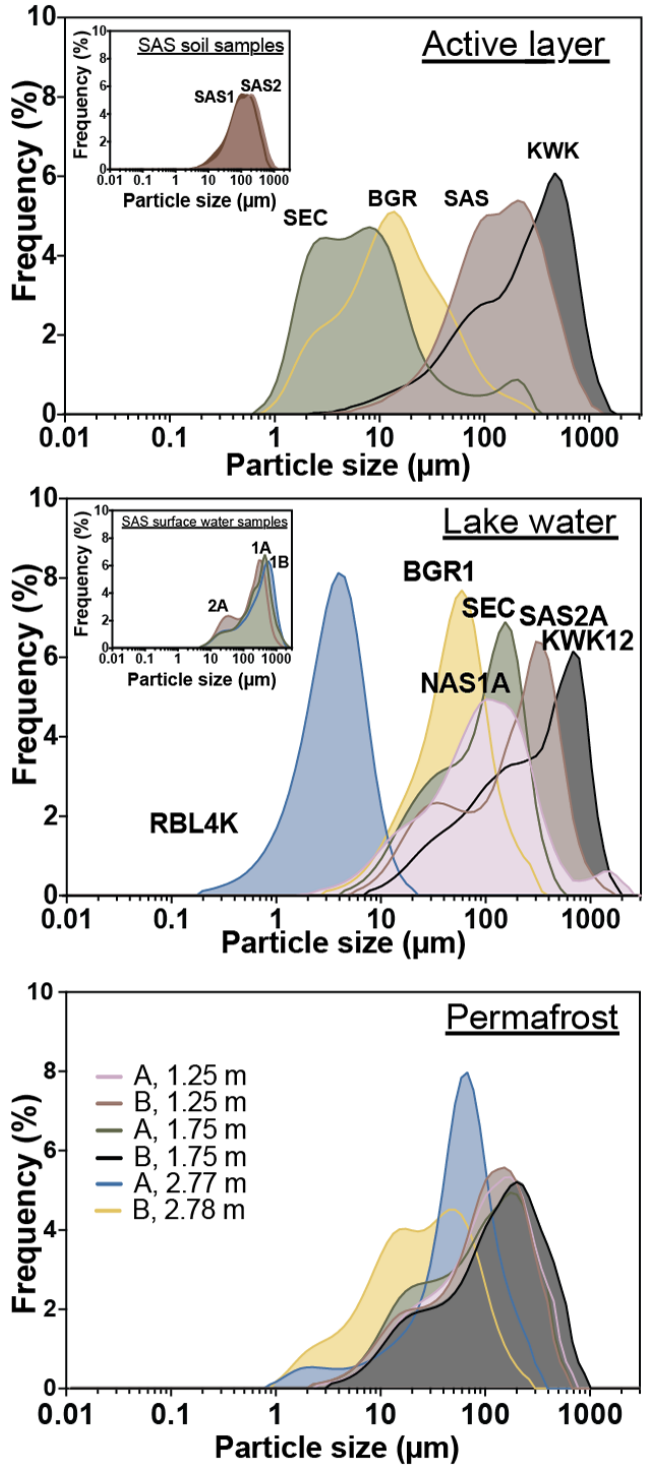

Figure 4. Distribution of particle sizes in lake water and permafrost soil samples. Insert in the top panel shows the soil sample particlesize distribution for both SAS valleys. The insert in the middle panel shows the particle-size distribution in three SAS lakes: SAS1A, SAS1B, and SAS2A. The bottom panel shows the particle-size distributions from the SAS2 permafrost core samples.

lake water particles at SEC was bimodal, and the particles encompassed a much wider range in soil than in the lakes.

\subsection{Lake properties}

The SAS lake surface waters differed significantly in their limnological properties from those of other thaw lakes and also from the rock-basin lakes (Table 3; 1way ANOVA). The SAS lakes had a mean $( \pm \mathrm{SD})$ surface DOC value of $11.5 \pm 2.4 \mathrm{mg} \mathrm{L}^{-1}$, that was significantly higher than the two other lake categories

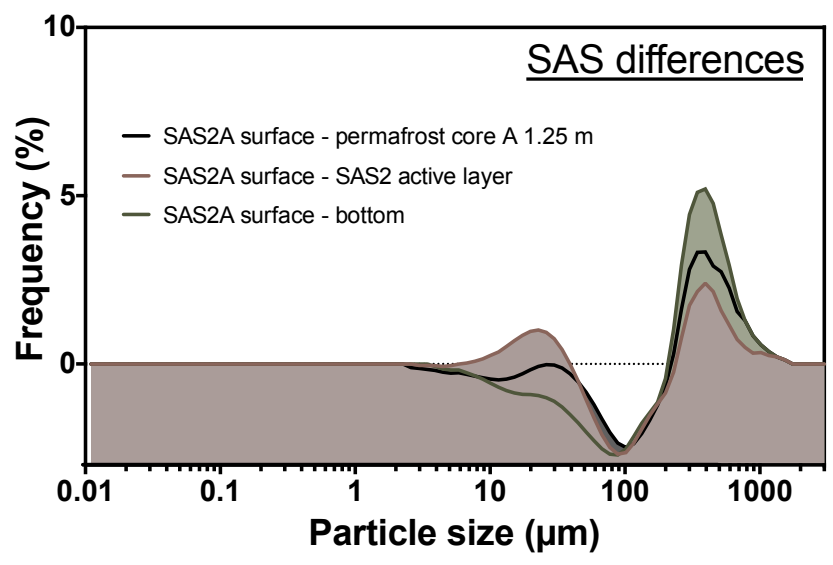

Figure 5. Difference spectra between the frequency distribution of particles in surface lake water (SAS2A) relative to active layer soil, permafrost and bottom lake water.

$(p<0.001)$, with an average of $4.08 \pm 1.4 \mathrm{mg} \mathrm{L}^{-1}$ for the other thermokarst lakes, and $10.6 \pm 3.1 \mathrm{mgL}^{-1}$ for the rock-basin lakes. The average surface $\mathrm{Chl} a$ concentration was also significantly higher for the SAS lakes (mean $\pm \mathrm{SD}=2.29 \pm 1.09 \mu \mathrm{g} \mathrm{L}^{-1}$ ) relative to the other categories (other thermokarst lakes mean $=0.897 \pm 0.43 \mu \mathrm{g} \mathrm{L}^{-1}$; rock-basin lakes mean $=1.39 \pm 0.50 \mu \mathrm{g} \mathrm{L}{ }^{-1} ; p=0.03$ ), as was surface $\mathrm{TN}$, which averaged $( \pm \mathrm{SD}) 0.58 \pm 0.10 \mathrm{mg} \mathrm{L}^{-1}$ in the SAS lakes, and $0.30 \pm 0.08$ and $0.61 \pm 0.20 \mathrm{mg} \mathrm{L}^{-1}$ in each of the other two categories, respectively $(p<0.01)$. TSS and maximum particle size (PSmax) values were variable within each lake type (Table 3), with no significant differences; the surface PSmax values were strikingly variable in rock-basin lakes, ranging over 3 orders of magnitude, but much more homogeneous among the SAS waters (mean of $384 \mu \mathrm{m}$ with a CV of $37 \%$ ).

Despite their shallow depths, the SAS lakes showed substantial differences between the top and bottom of the water column, which was also a feature of the other thaw lakes (Table 3). A two-way ANOVA for depth and the two thaw lake types (SAS versus the other thaw lakes) showed that overall there were significant increases at depth in $\operatorname{SRP}(F=23 ; p=0.03)$; TN $(F=18 ; p=0.02)$ and Chl $a(F=28 ; p=0.03)$, with no significant $(p>0.05)$ top-bottom differences in DOC, TSS or PSmax. Consistent with the 1-way analysis for all three lake types, this 2-way analysis (both depths) showed that SAS lakes had significantly higher concentrations of DOC $(F=65 ; p<0.0001)$ and $\mathrm{TN}(F=32 ; p=0.004)$ relative to other thaw lakes. However, the SAS lakes had significantly lower concentrations of TSS ( $F=23 ; p=0.05)$, which were especially high in NAS1A and BGR2, and there were no significant differences $(p>0.05)$ between the two groups of thaw lakes in terms of SRP, Chl $a$ or PSmax.

Ammonium and nitrate were not analyzed routinely, but the surface waters of the SAS lakes sampled during late 
Table 3. Limnological properties of study sites. Zs, sample depth, soluble reactive phosphorus (SRP, in $\mu \mathrm{g} \mathrm{L}^{-1}$ ), total nitrogen (TN, in $\mathrm{mg} \mathrm{L}^{-1}$ ), dissolved organic carbon (DOC, in $\mathrm{m} \mathrm{L}^{-1}$ ), Chlorophyll $a$ (Chl $a$, in $\mu \mathrm{g} \mathrm{L}^{-1}$ ), total suspended solids (TSS, in $\mathrm{mg} \mathrm{L}^{-1}$ ); $\mathrm{PS}_{\max }$, maximum frequency of particle size distribution $(\mu \mathrm{m})$. The $\mathrm{S}$ samples correspond to surface at $0 \mathrm{~m}$, and the B samples correspond to the maximum depth of each lake.

\begin{tabular}{llrrrrrr}
\hline Lake & Zs & SRP & TN & DOC & Chl $a$ & TSS & PSmax \\
\hline SAS1A & S & 1.01 & 0.58 & 10.4 & 3.31 & 5.31 & 452 \\
& B & 5.48 & 1.76 & 13.4 & 4.13 & 33.0 & 200 \\
SAS1B & S & 1.44 & 0.70 & 14.7 & 3.44 & 7.43 & 592 \\
& B & 2.18 & 0.89 & 14.6 & 6.22 & 11.3 & 262 \\
SAS2A & S & 1.42 & 0.42 & 8.50 & 0.94 & 17.6 & 300 \\
& B & 1.17 & 0.40 & 9.00 & 3.34 & 4.56 & 200 \\
SAS2B & S & 1.12 & 0.61 & 12.8 & 1.54 & 6.00 & 344 \\
& B & 8.34 & 1.88 & 22.0 & 7.78 & 16.5 & 1338 \\
SAS2C & S & 1.03 & 0.59 & 11.0 & 2.24 & 4.62 & 229 \\
& B & 5.76 & 1.71 & 21.0 & 1.84 & 15.8 & 229 \\
KWK12 & S & 0.41 & 0.41 & 6.30 & 1.12 & 6.52 & 592 \\
& B & 1.78 & 0.63 & 7.60 & 6.24 & 27.1 & 200 \\
SEC & S & 0.75 & 0.26 & 2.90 & 1.02 & 6.97 & 153 \\
& B & 1.56 & 0.35 & 3.90 & 1.58 & 61.6 & 175 \\
BGR1 & S & 0.42 & 0.24 & 2.40 & 0.49 & 4.57 & 59 \\
& B & 2.06 & 0.51 & 3.20 & 13.4 & 34.7 & 59 \\
BGR2 & S & 1.85 & 0.38 & 5.10 & 0.92 & 30.8 & 229 \\
NAS1A & S & 4.18 & 0.25 & 3.80 & 0.32 & 112 & 102 \\
& B & 3.25 & 0.23 & 3.30 & 0.07 & 163 & 102 \\
NAS1H & S & 1.80 & 0.24 & 4.00 & 1.51 & 10.9 & 102 \\
RBL4K & S & 0.47 & 0.74 & 8.10 & 1.48 & 4.00 & 4 \\
POND9K & S & 4.84 & 0.81 & 15.1 & 1.16 & 3.22 & 13 \\
RBL9K & S & 3.66 & 0.54 & 10.2 & 0.88 & 1.28 & 200 \\
RBLOlsha & S & 1.09 & 0.36 & 9.10 & 2.05 & 1.46 & 175 \\
\hline & & & & & & & \\
\hline
\end{tabular}

June 2014 contained undetectable concentrations of nitrate $\left(<10 \mu \mathrm{g} \mathrm{NL}^{-1}\right)$ and substantial concentrations of ammonium: 64 (SAS1A), 58 (SAS1B), 49 (SAS2A), 60 (SAS2B) and $74(\mathrm{SAS} 2 \mathrm{C}) \mu \mathrm{g} \mathrm{NH}_{4}^{+}-\mathrm{NL}^{-1}$. Much higher values were recorded in the anoxic bottom waters of two of the lakes: 1021 (SAS1A) and 178 (SAS1B) $\mu \mathrm{g} \mathrm{NH}_{4}^{+}-\mathrm{NL}^{-1}$, but values were similar to surface waters in SAS2A $\left(48 \mu \mathrm{g} \mathrm{NH}_{4}^{+}\right.$$\mathrm{NL}^{-1}$ ).

\subsection{Bacterial abundance and productivity}

BA in the surface waters varied over an order of magnitude among SAS lakes, from 0.2 to $3.1 \times 10^{6}$ cells $\mathrm{mL}^{-1}$, and did not significantly differ from the other lake types (Table $4 ; p>0.05)$. BP rates varied by a factor of six among SAS lakes, from 0.25 to $1.68 \mu \mathrm{g} \mathrm{CL}^{-1} \mathrm{~h}^{-1}$, and as for cell concentration, there were no significant differences among the categories of lakes. BG were similarly variable, ranging from 1.9 to $113 \mathrm{fg} \mathrm{cell}^{-1} \mathrm{~d}^{-1}$. Four of the five values from SAS surface waters were well above (factor of two or greater) any of the thermokarst or rock-basin lakes of the two other categories. Overall, the mean value for SAS waters $(69 \mathrm{fg}$ cell $\left.^{-1} \mathrm{~d}^{-1}\right)$ was significantly higher than the others $(F=5.0$; $p=0.026$ ).
Table 4. Bacterial properties of study sites. Zs, sample depth, bacterial abundance $\left(\mathrm{BA}\right.$, in $10^{6}$ cells $\left.\mathrm{mL}^{-1}\right)$, bacterial production rate (BP, in $\mu \mathrm{g} \mathrm{CL}^{-1} \mathrm{~h}^{-1}$ ), and bacterial community specific growth rates $\left(B G\right.$, in $\left.\mathrm{d}^{-1}\right)$. The $S$ samples correspond to surface at $0 \mathrm{~m}$, and the B samples correspond to the maximum depth of each lake.

\begin{tabular}{llrrr}
\hline Lake & Zs & BA & BP & BG \\
\hline SAS1A & S & 0.319 & 0.896 & 3.72 \\
& $\mathrm{~B}$ & 2.59 & 1.074 & 0.550 \\
SAS1B & $\mathrm{S}$ & 0.203 & 0.855 & 5.58 \\
& $\mathrm{~B}$ & 0.867 & 0.923 & 1.41 \\
SAS2A & $\mathrm{S}$ & 3.15 & 0.254 & 0.107 \\
& $\mathrm{~B}$ & 1.57 & 1.676 & 1.42 \\
SAS2B & $\mathrm{S}$ & 0.321 & 0.804 & 3.32 \\
& $\mathrm{~B}$ & 1.26 & 0.588 & 0.619 \\
SAS2C & $\mathrm{S}$ & 0.282 & 1.34 & 6.30 \\
& $\mathrm{~B}$ & 1.99 & 0.547 & 0.364 \\
KWK12 & $\mathrm{S}$ & 3.53 & 2.34 & 0.879 \\
& $\mathrm{~B}$ & 1.55 & 1.164 & 0.996 \\
SEC & $\mathrm{S}$ & 1.98 & 0.885 & 0.593 \\
& $\mathrm{~B}$ & 0.994 & 0.650 & 0.867 \\
BGR1 & $\mathrm{S}$ & 2.79 & 0.264 & 0.125 \\
& $\mathrm{~B}$ & 1.03 & 0.609 & 0.784 \\
BGR2 & $\mathrm{S}$ & 1.89 & 1.312 & 0.920 \\
NAS1A & $\mathrm{S}$ & 1.71 & 1.188 & 0.921 \\
& $\mathrm{~B}$ & 1.16 & 0.785 & 0.897 \\
NAS1H & $\mathrm{S}$ & 0.864 & 1.253 & 1.92 \\
RBL4K & $\mathrm{S}$ & 2.46 & 0.371 & 0.200 \\
POND9K & $\mathrm{S}$ & 2.64 & 0.791 & 0.397 \\
RBL9K & $\mathrm{S}$ & 2.78 & 0.597 & 0.285 \\
RBLOlsha & $\mathrm{S}$ & 0.819 & 0.849 & 1.37 \\
\hline
\end{tabular}

\subsection{Size-fractionated solids and associated bacteria}

In SAS2A, the mass of suspended solids decreased sharply with filter size, and the $<1 \mu \mathrm{m}$ fraction contained only $5 \%$ of the total value (Fig. 6). Similar trends were observed in the other lakes, with the exception of NAS1A where almost all of the suspended solids passed through the 35 and $3 \mu \mathrm{m}$ filters, and $34 \%$ even passed through the $1 \mu \mathrm{m}$ filter. In terms of bacterial cells, highest counts were in the total or $<35 \mu \mathrm{m}$ fraction, with the exception of NAS1A, which peaked in the $<3 \mu \mathrm{m}$ fraction. Only $28 \%$ of the maximum counts occurred in the $<1 \mu \mathrm{m}$ fraction in SAS2A samples, and this fraction was similarly low in SEC (23\%). Higher percentages of maximum occurred in the $<1 \mu \mathrm{m}$ fraction in RBL4K (43\%), KWK12 (52\%), BGR1 (52\%) and NAS1A (87\%).

The BP data showed a more striking pattern (Fig. 6). Total production was maximal in the unfiltered (total) or $<35 \mu \mathrm{m}$ fraction, but the $<1 \mu \mathrm{m}$ fraction accounted for only $26 \%$ of the maximum in SAS2A, and was even lower in most of the other lakes: $11 \%$ (NAS1A), $11 \%$ (RBL4K), $16 \%$ (KWK12), and $14 \%$ (BGR1). An average value of $39 \%$ was recorded in SEC. BG (bacterial community specific growth rates) were highly variable among size fractions, ranging 


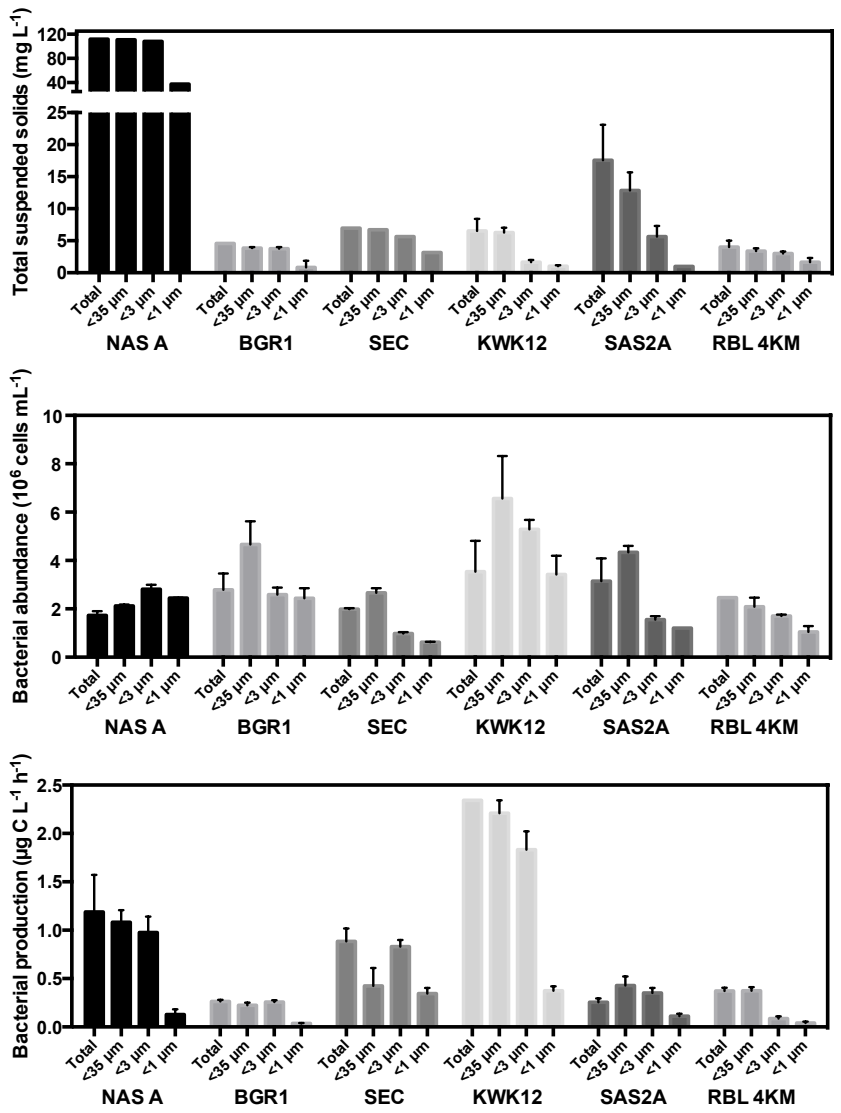

Figure 6. Size-fractionated total suspended solids (TSS), bacterial abundance (BA), bacterial production (BP), and bacterial cellspecific growth rates $(\mathrm{BG})$ from five thermokarst lakes and one rock-basin lake. Each is the mean $\pm \mathrm{SD}$ of triplicate samples.

from a minimum of $0.021 \pm 0.0035 \mathrm{~d}^{-1}$ in the $<1 \mu \mathrm{m}$ size fraction of BGR1 to a maximum of $1.1 \pm 0.032 \mathrm{~d}^{-1}$ in the $<3 \mu \mathrm{m}$ fraction of SEC (Fig. 6). In the SAS2A analysis, rates were two times higher in the $<3 \mu \mathrm{m}$ than in the $<1 \mu \mathrm{m}$ fraction. Similarly, in all of the other lake waters, highest BG were in fractions above $1 \mu \mathrm{m}$ : Total (NAS1A); Total and $<3 \mu \mathrm{m}$ (BGR1); $<3 \mu \mathrm{m}$ (SEC); Total (KWK12) and Total and $<35 \mu \mathrm{m}$ (RBL4K). The free-living cell fraction $(<1 \mu \mathrm{m})$ showed rates that were a small percentage of the production per cell in the unfiltered samples in RBL4K (27\%); KWK12 $(16 \%)$; NAS1A $(8 \%)$ and BGR1 (16\%).

\subsection{Enrichment experiment}

Over the course of the experiment (Fig. 7), there was no significant change in Chl $a$ concentrations, either with time or among treatments (repeated measures ANOVA, $p>0.05$ ). There was a significant drop in bacterial cell abundance in all treatments by day 5 (BA; effect of time $F=39 ; \mathrm{p}=0.025$ ) but no significant change in production rates (BP, $p>0.05$ ). Although there was no significant overall effect of time and treatment on bacterial growth rates $(\mathrm{BG}$, carbon production

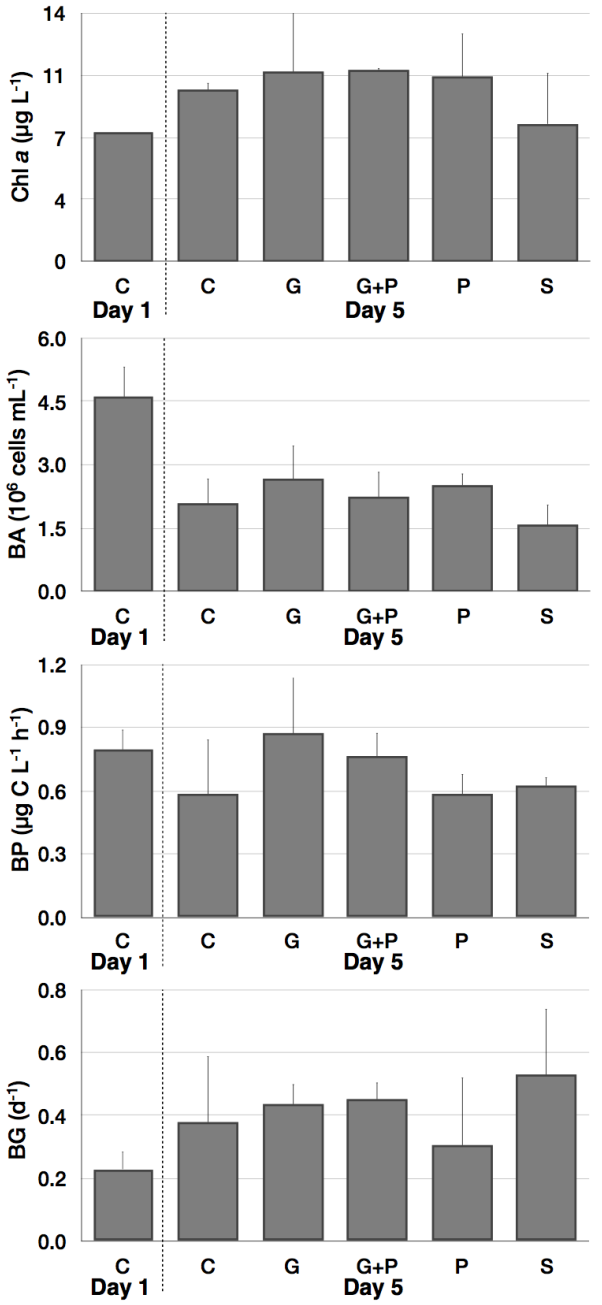

Figure 7. Planktonic variables in the 5-day experiment with amendments of glucose $(G)$, glucose plus phosphorus $(G+P)$, phosphorus $(\mathrm{P})$, and palsa soil $(\mathrm{S})$ to SAS1B lake water. The control $(\mathrm{C})$ is shown on both day 1 and day 5 . Each value is the mean \pm SD of triplicate samples.

rates per cell; $p>0.05)$, there was a significant interaction effect between time and treatment $(F=4.9 ; p=0.026)$. Further analysis (Holm-Sidak pairwise comparisons) showed that while most of BG had not changed statistically, there was a large significant increase between days 1 and 5 in the soil addition treatment (146\% average increase; $t=2.9$; $p=0.034)$ and in the carbon + phosphorus $(\mathrm{G}+\mathrm{P})$ enrichment (187\% increase; $t=3.34 ; p=0.022)$.

\section{Discussion}

The permafrost peatland soils analyzed here contained abundant resources for bacterial development, including biologically accessible carbon, nitrogen, and phosphorus. Degradation of the SAS permafrost peatland landscape was observed 
to be already underway, with the transfer of material from permafrost palsa mounds and surface soils into thermokarst lakes. This transfer was evident at the landscape level, from patterns of palsa size and degradation (Fig. 2), as well as via within-lake evidence of similarities between particles, and at the microbial scale, via the abundant particle-attached bacterial communities that likely benefit from access to particles and flocculent matter. The favorable conditions available to bacterial communities in permafrost peatland thaw lakes resulted in abundant bacterial communities with high BG. These bacterial communities seemed less likely to be controlled by bottom-up processes, as is more commonly observed in freshwater ecosystems (Pace and Cole, 1994), than by top-down regulation.

\subsection{Organic carbon enrichment}

There is an estimated $1.048 \times 10^{6} \mathrm{~km}^{2}$ of permafrost peatland in North America, half of which is located in areas of sporadic or isolated permafrost like the SAS region of the present study (Tarnocai et al., 2009). The surface soil and permafrost cores from the SAS region were abundant in organic carbon, with $\sim 50 \% \mathrm{C}$-content (by dry-weight) down to $2 \mathrm{~m}$ depth in the permafrost cores (Fig. 3), comparable to peatland soils elsewhere. A study of peat cores from five North-American sites showed that the concentration was consistently around $50 \% \mathrm{C}$ dry-weight (Gorham and Janssens, 2005), as was also observed in the surface SAS1 active layer and in the upper layers of the two permafrost cores. Similarly, a synthesis of peat data from nine studies in the Northern Hemisphere (Gorham et al., 2012) yielded a mean value $( \pm \mathrm{SD})$ of $50.1(2.9) \%$. These carbon values are much higher than observed in other types of Arctic soils. For example, the carbon content of active layer soil from a polygonal tundra of the Lena Delta ranged from 1.5 to $3 \%$ dry-weight (Höfle et al., 2013), an order of magnitude less than values in the SAS soil. Lower carbon concentrations were also measured in a study of permafrost soils of the Arctic tundra of Northwest Territories, which were $6.5 \%$ $\mathrm{C}$ (Moquin and Wrona, 2015), and in the lithalsa mounds surrounding BGR1 (Fig. 1), where the carbon content of the active layer was less than $1 \%$ (ADAPT, 2014).

The degrading palsas provided a rich potential source of organic carbon to their associated lakes (Fig. 2). Paleoecological studies (Arlen-Pouliot and Bhiry, 2005; Fillion et al., 2014) have shown that the peat in the SAS valley accumulated in bogs over a 1400-year period from around 1800 to 400 years before the present, and was then uplifted in palsas during the period of permafrost aggradation during the Little Ice Age, 400 to 200 years before present day. From the end of the 19th century onwards, the SAS palsas have been thawing and eroding, with the production and eventual infilling of associated thermokarst lakes (palsa lakes), and this warming phase appears to have accelerated over the last two decades (Bhiry et al., 2011). As shown in the permafrost core analy- sis (Table 2), the potential organic input to thermokarst lakes includes not only particulate organic carbon but also DOC. Two contrasting scenarios have been identified for the effects of thawing permafrost on carbon transport in northern catchments (Vonk et al., 2015): (1) decreased net export of carbon as a result of increased flow path lengths, residence times and decomposition in a deeper active layer, or (2) increased net export as a result of thermal erosion and mobilization of particulate and dissolved organic carbon. The SAS valley is currently in the "pulse phase" of carbon mobilization, which as noted by Vonk et al. (2015), is typically dominated by the export of particulate materials. However, the high DOC of the SAS lake waters, significantly above that in the other lake types, also attests to a substantial export of DOC from the SAS palsas to their associated lakes, and is consistent with the permafrost thaw analyses. The low absorption slope values in the SAS lakes indicate a predominantly terrestrial origin of DOC in these lakes (Fichot and Benner, 2012), and the similarity in slope values between the permafrost cores and the lake waters also supports this close linkage between land and water (Fig. S1).

\subsection{Nutrient enrichment}

In addition to carbon-enrichment, the SAS soil also likely represents a nutrient-rich substrate for bacterial metabolic activity (Table 1). The soil $\mathrm{N}$ concentrations were low relative to $\mathrm{C}$, reflecting the stoichiometry of ancient moss tissue, however there were large standing stocks of $\mathrm{N}$, and the high ammonium levels in the lake water implies that nitrogen was in abundant supply for planktonic microbial growth processes. The SAS surface soil had nearly three times as much phosphorus and more than five times as much iron relative to concentrations found in other Sphagnum peat bogs (Gorham and Janssens, 2005). It also had 1.6 times the concentration of phosphorus and three times the amount of calcium when compared to permafrost soil from the Northwest Territories (Moquin and Wrona, 2015), though only a fraction (5\%) of the magnesium observed in the latter study.

Part of the observed differences when compared to these other regions is related to the long-term history of the Hudson Bay region. Enrichment Factors (EF) indicated that phosphorus was above the global average for phosphorus concentrations in soil $(\mathrm{EF}=15.9)$, demonstrating long-term transfer of this elements from other sources, such as via atmospheric deposition or hydrological transfer (from surrounding rocks or terrestrial zones). The permafrost thawing analyses showed a release of nitrate but no evidence of soluble phosphorus release, except from the bottom-core samples that produced SRP concentrations that were 2- to 30-times above current lake water values (Table 2). This coastal region of eastern Hudson Bay was submerged beneath the Tyrell Sea from immediately after the retreat of the ice cap about 7900 years ago to emersion from the sea about 6000 years before the present, and previous paleoecological studies on the deeper 
strata of the SAS valley sampled in the bottom core show that these are ancient marine sediments (Arlen-Pouliot and Bhiry, 2005; Fillion et al., 2014). This would account for their higher phosphorus release relative to that from the upper core. Deep thawing of the palsas during the final stages of their collapse could therefore have a major P-enrichment effect on the associated thermokarst lake ecosystems.

Inorganic nutrient release from thawing and eroding permafrost has been documented at sites elsewhere, but with large variations among regions and landscape types (Vonk et al., 2015). Slumping of permafrost soils into Alaskan streams increases their inorganic and organic concentrations (Bowden et al., 2008), but phosphorus adsorption onto clays may decrease SRP concentrations in some mineral permafrost environments (Breton et al., 2009). Nitrate export from the Kuparuk River catchment on the Alaska North Slope increased 5-fold between the late 1970s and early 2000s and may have been related to permafrost soil and vegetation effects (McClelland et al., 2007). These processes may also operate in the peatland permafrost sites studied here.

\subsection{Particle enrichment}

The SAS permafrost peatland lakes were rich in particulate material, with substantially larger particles than nonpermafrost-affected rock-basin lake RBL4K, and they contained some of the largest particles amongst thermokarst lakes studied (Fig. 4). Much finer particles over a narrower size range were recorded in the northern permafrost lakes NAS1A and BGR1, reflecting their mineral permafrost catchments. The close correspondence between the active layer, permafrost and lake particle size distribution at SAS2 (Fig. 5), is evidence that this richness of particles in the peatland lakes is derived from the thermo-erosion of their associated palsas. The small but conspicuous shift to larger particles in the SAS surface waters may indicate the production of aggregates by flocculation that are maintained in the upper water column by virtue of their low density and therefore slow sinking speeds. The production of flocs was observed when SAS water was brought into the laboratory and stored in clear glass bottles without mixing for several days (B. N. Deshpande, unpublished observations), and may be favored by the high DOC concentration in these waters. In contrast, the deeper waters showed an increase in fine particles, contrary to what might be expected from Stokes' Law based upon size relationships. The origin of this difference is unknown at this time, but it could be the result of fine, highdensity mineral particles settling out from the overlying water column. The extreme thermal stratification and physical stability of these waters (Deshpande et al., 2015; Przytulska et al., 2016) indicates that only particles of small size or low density would be maintained in the water column.

\subsection{Bacterial association with particles}

There was clear evidence that the high particle-loading of peatland SAS waters affected its bacterial ecology. Less than $30 \%$ of the total BA and BP rates were associated with the free-living category, operationally defined here as passing through a $1 \mu \mathrm{m}$ filter, and this effect was even more pronounced for bacterial growth rates (BG), which were $50 \%$ lower in the $<1 \mu \mathrm{m}$ than in the $<3 \mu \mathrm{m}$ fraction, implying much faster growth rates of bacteria on particles in the size range $1-3 \mu \mathrm{m}$. In SAS2A, as in many of the other northern lakes, bacterial populations and production appeared to be distributed across the full range of particle sizes (Fig. 6). This is consistent with studies across a range of salt- and freshwater environments showing that particle-attached bacteria are favored in environments with a high availability of particulate habitats (Lami et al., 2009; Kirchman and Ducklow, 1987; Kirchman and Mitchell, 1982).

There are several sources of experimental error that must be considered when interpreting particle analyses of this sort. Firstly, it is difficult to obtain a reliable count of particlebased bacteria. Our shaking of the samples would have broken up and released cells from larger aggregates, but dislodging bacteria from particles is notoriously difficult. Even sonication is not completely effective, and addition of a detergent along with sonication can result in a pronounced increase in cell concentrations in sediment-laden waters (Yoon and Rosson, 1990). It is therefore likely that the cell concentrations in the present study were underestimated, especially in the $>1 \mu \mathrm{m}$ fractions. This would imply an even greater representation by particle-based cells to the total community abundance, but it would also have led to an overestimation of the production rates per cell biomass. Experiments based on size-fractionation by filtering are always challenging because of the interactions between particle and the filters. Filtering water results in the breakup of particles upon collision with the filter surface, causing two important effects: (1) an increased bioavailability of organic particles (Amon and Benner, 1996); and (2) potential detachment of particleattached bacterial from their organic-matter habitat. Filter blocking may have also retained smaller fractions, including free-living cells. Although the exact rates per fraction in the present study, as in all such studies, must be interpreted with caution, the distribution of cells and activities across multiple fractions and the low values in the $<1 \mu \mathrm{m}$ fraction point to the importance of particle-based bacteria in this system. This was not unique to the organic-rich SAS waters, but was found in several of the other lakes. These results are consistent with a previous study of five lakes in the mineral-rich KWK area, which showed a substantially higher proportion of particle-attached bacteria $(62 \pm 30 \%$ in the $>3 \mu \mathrm{m}$ sizefraction) and high BP $(59 \pm 30 \%)$ by these groups (Roiha et al., 2015). The BG patterns of some of these lakes are also consistent with data elsewhere; for example, Kirchman and Mitchell (1982) found that particle-attached bacteria ac- 
Table 5. Comparison of bacterial abundances (BA, $10^{6}$ cells $\left.\mathrm{mL}^{-1}\right)$ and production rates $\left(\mathrm{BP}, \mu \mathrm{g} \mathrm{CL}^{-1} \mathrm{~h}^{-1}\right)$ from thermokarst lakes with other aquatic environments. ${ }^{*}$ Trophic status based on Chl $a$ concentrations only.

\begin{tabular}{|c|c|c|c|c|c|}
\hline Name & Location & Trophic status & BA & $\mathrm{BP}$ & Reference \\
\hline Pääjärvi & Finland, in winter & Dystrophic & $1.2-1.7$ & $0.0083-0.096$ & Tulonen et al. (1994) \\
\hline 16 ponds & Subarctic Finland & Oligotrophic & $1.75-2.75$ & $0.063-0.15$ & Roiha et al. (2012) \\
\hline $\begin{array}{l}\text { Mesocosm } \\
\text { of small } \\
\text { tundra lake }\end{array}$ & $\begin{array}{l}\text { Mackenzie Delta, } \\
\text { Northwest Territories }\end{array}$ & Mesotrophic & - & 0.16 & Moquin and Wrona (2015) \\
\hline$S A S 2 A$ & Subarctic Québec & Dystrophic, mesotrophic & 3.1 & 0.25 & This study \\
\hline$B G R 1$ & Subarctic Québec & Oligotrophic & 2.8 & 0.26 & This study \\
\hline Stukely & Southern Québec & Mesotrophic* & 2.7 & 0.30 & del Giorgio et al. (1997) \\
\hline 16 lakes & Subarctic Sweden & Oligotrophic, dystrophic & $2.4-0.4$ & $0.012-0.32$ & Karlsson et al. (2001) \\
\hline$R B L 4 K$ & Subarctic Québec & Oligotrophic & 2.5 & 0.37 & This study \\
\hline SEC & Subarctic Québec & Oligotrophic, mesotrophic & 2.0 & 0.88 & This study \\
\hline SAS1A & Subarctic Québec & Dystrophic, mesotrophic & 0.32 & 0.90 & This study \\
\hline NAS1A & Subarctic Québec & Oligotrophic, dystrophic & 1.7 & 1.2 & This study \\
\hline$S A S 2 C$ & Subarctic Québec & Dystrophic, mesotrophic & 0.28 & 1.3 & This study \\
\hline Lovering & Southern Québec & Oligotrophic* & 3.4 & 1.35 & del Giorgio et al. (1997) \\
\hline Massawippi & Southern Québec & Mesotrophic* & 3.0 & 1.69 & del Giorgio et al. (1997) \\
\hline Magog & Southern Québec & Eutrophic* & 3.38 & 1.88 & del Giorgio et al. (1997) \\
\hline Central & Southern Québec & Mesotrophic* & 3.3 & 2.15 & del Giorgio et al. (1997) \\
\hline Brome & Southern Québec & Eutrophic* & 3.4 & 2.24 & del Giorgio et al. (1997) \\
\hline$K W K 12$ & Subarctic Québec & Mesotrophic, dystrophic & 3.5 & 2.34 & This study \\
\hline Waterloo & Southern Québec & Hypereutrophic* & 5.9 & 3.81 & del Giorgio et al. (1997) \\
\hline
\end{tabular}

counted for $<10 \%$ of the total bacterial populations but contributed substantially to total microbial activity.

\subsection{Controls on bacterial abundance and productivity}

Bacterial abundance in the thermokarst lakes sampled here ranged from 0.20 to $3.5 \times 10^{6}$ cells $\mathrm{mL}^{-1}$, which falls towards the higher end of the range for comparable aquatic ecosystems (Table 5). For example, in study of 16 lakes located in subarctic Sweden, bacterial concentrations ranged from 0.4 to $2.4 \times 10^{6}$ cells $\mathrm{mL}^{-1}$ (Karlsson et al., 2001), and in a humic, boreal lake, bacterial concentrations ranged from 1.2 to $1.7 \times 10^{6}$ cells $\mathrm{mL}^{-1}$ in winter (Tulonen et al., 1994).

The BP rates in the thermokarst lakes sampled here were also at the high end of the range in comparable systems (Table 5), from 0.25 to $2.3 \mu \mathrm{g} \mathrm{CL} \mathrm{L}^{-1} \mathrm{~h}^{-1}$, with an average $\left( \pm\right.$ SD) of $0.92( \pm 0.46) \mu \mathrm{g} \mathrm{C} \mathrm{L}{ }^{-1} \mathrm{~h}^{-1}$. These rates are more comparable with those observed in southern Québec aquatic ecosystems, and productive systems elsewhere, for example the high-nutrient Butron River, Vizcaya, Spain (Table 4). In this river, free-living bacteria had a production rate of $5.8 \mu \mathrm{g} \mathrm{CL}^{-1} \mathrm{~h}^{-1}$, with particle-attached communities contributing $2.97 \mu \mathrm{g} \mathrm{CL}^{-1} \mathrm{~h}^{-1}$ of bacterial-production (Iriberri et al., 1990).

Such comparisons with other sites need to be made with caution because they rest on a number of untested assumptions. Notably, we used a single factor for conversion between leucine uptake to carbon production concentrations, and assumed a 2-fold isotopic dilution of leucine in the nat- ural environment, observed in certain subarctic ecosystems (Simon and Kirchman, 1988; Simon and Azam, 1989) and as has been employed for a wide range of bacterial production studies elsewhere (Judd et al., 2006; del Giorgio et al., 1997; del Giorgio and Bouvier, 2002). However, given the wide-range of DOC concentrations and unique characteristics of thermokarst lakes, it is likely that the true conversion factors would lie on a wider range, as found in Pulido-Villena and Reche (2003). If ambient leucine concentrations follow the trend of measured total DOC concentrations, then production rates may have been especially underestimated in the SAS incubations. This should not have influenced the pattern amongst size fractions, however, as noted above, errors associated with cell counts for the particle-associated fractions may have affected the estimates of rates per biomass.

The enrichment experiment in the present study showed that there was no significant effect of either glucose or phosphorus when added separately to the SAS peatland lake waters (Fig. 7). These results imply that bacterial stocks and production were not strongly limited by carbon supply, nor were they subject to primary phosphorus limitation. This contrasts with results from the permafrost-influenced, turbid waters of the Mackenzie River, Northwest Territories Canada, where short-term glucose enrichment resulted in a 4-fold increase in leucine uptake rates (Vallières et al., 2008). They also contrast with enzymatic analyses of Greenland lakes that implied strong primary phosphorus limitation (Burpee et al., 2016). Chl $a$ levels also showed no significant 
effect of enrichment, in contrast to such experiments in High Arctic lakes (Bonilla et al., 2005). However, for the addition of glucose plus phosphorus, and also for the soil addition treatment, there was a significant increase in BG (Fig. 7). This implies a combined stimulatory enrichment effect on bacterial production of the palsa permafrost soils eroding into the SAS thermokarst lakes.

Other studies have shown that DOM-enrichment increased heterotrophic metabolism, sometimes at the expense of autotrophic metabolic activity (Forsström et al., 2013). In an Arctic tundra lake of the Northwest Territories, addition of permafrost soil resulted in decreased bacterial production in the pelagic zone, but increased rates in the benthic zone (Moquin and Wrona, 2015). A recent study of Arctic lakes in southwest Greenland found that microbial populations were primarily phosphorus-limited, and that this P-limitation increased with the availability of DOM (Burpee et al., 2016). In an area of discontinuous permafrost in northern Sweden, addition of terrestrial carbon to aquatic bacterial samples resulted in a four- to seven-fold increase in respiration rates, with only a small proportion of the available carbon (1-12\%) contributing to cellular biomass and the dominant portion respired to $\mathrm{CO}_{2}$ (Roehm et al., 2009).

All of the limnological and microbial measurements point to the SAS peatland lakes as favorable environments for bacterial production. The BG values show that SAS lakes were outliers amongst thermokarst lakes, with significantly elevated rates (Table 4). These rates are also on the higher end of observations made across a wide trophic range of lakes from other regions (del Giorgio et al., 1997; Smith and Prairie, 2004). The lack of response of cellular rates to either phosphorus or carbon added singly also implies sufficiency, and although there was an apparent rise in growth rates in response to soil and carbon + phosphorus $(\mathrm{G}+\mathrm{P})$, this was at the limit of significance and was not translated into an increase in BA (Fig. 7). In fact populations fell in all of the incubations, despite $\mathrm{BG}$ rates that remained the same or higher. In combination, these observations suggest that bacterial biomass in the SAS peatland lakes is controlled by top down processes rather than by bottom-up, substrate supply rates. This might involve viral lysis, as in planktonic bacterial systems elsewhere (e.g., Lymer et al., 2008) or it may be the result of intense grazing by bactivores. These waters contain high concentrations of zooplankton, including Daphnia (Bégin, 2015) that can filter picocyanobacteria (Przytulska et al., 2015) and probably heterotrophic bacteria (Rautio and Vincent, 2006). Studies on SAS2A have shown that they contain abundant ciliates, heterotrophic nanoflagellates and mixotrophic phytoplankton (Przytulska et al., 2016; Bégin, 2015), all of which may exert a control on bacterial densities. In these environments, enriched by soil particles, carbon and nutrients released from thawing and eroding permafrost, bacterial stocks may be ultimately capped by loss rather than gain processes.

\section{Data availability}

Soil and other environmental data from this study are available in ADAPT (2014).

\section{The Supplement related to this article is available online at doi:10.5194/bg-13-4411-2016-supplement.}

Acknowledgements. This study was made possible with financial support from the Natural Sciences and Engineering Research Council of Canada (NSERC), the Canada Research Chair program, and the Québec nature and technology research funds (FRQNT). Financial and logistical support are further provided by the Centre for Northern Studies (Université Laval), the ADAPT (Arctic Development and Adaptation to Permafrost in Transition) Discovery Frontiers grant, and the Northern Science Training Program. We are grateful to P. Bégin, J. Comte, A. Przytulska-Bartosiewicz, V. Mohit, and C. Tremblay for their help in the field, and M.-J. Martineau, and J. Comte for laboratory support. We thank I. Laurion (INRS-ETE) for flow cytometry and F. Bruyant (Takuvik, Universite Laval) for the radioactivity laboratory. We thank D. Sarrazin and S. Aebischer for permafrost core sampling, and the CEN-ADAPT team for core and CHN analysis: G. Labrecque, A.-S. Carbonneau, J. Roger and M. Lemay. We thank S. Prémont at the INRS-ETE laboratory and D. Cayer at Université Laval FFGG laboratory for support and guidance with sample analysis. We thank I. Laurion, F. Maps, J. Boike and two anonymous reviewers for their comments on earlier versions of this manuscript.

Edited by: M. Tzortziou

Reviewed by: two anonymous referees

\section{References}

Acinas, S. G., Antón, J., and Rodríguez-Valera, F.: Diversity of freeliving and attached bacteria in offshore western Mediterranean waters as depicted by analysis of genes encoding 16S rRNA, Appl. Environ. Microbiol., 65, 514-522, 1999.

ADAPT: Carbon, nitrogen and water content of the active layer from sites across the Canadian Arctic, v. 1.0, Nordicana, D21, doi:10.5885/45327AD-5245D08606AB4F52, 2014.

Alldredge, A. L. and Silver, M. W.: Characteristics, dynamics and significance of marine snow, Progr. Oceanogr., 20, 41-82, 1988.

Amon, R. M. W. and Benner, R.: Bacterial utilization of different size classes of dissolved organic matter, Limnol. Oceanogr., 41, 41-51, 1996.

Arlen-Pouliot, Y. and Bhiry, N.: Palaeoecology of a palsa and a filled thermokarst pond in a permafrost peatland, subarctic Québec, Canada, Holocene, 15, 408-419, 2005.

Bégin, P.-N.: Abondance et diversité des rotifères dans les mares de thermokarst subartiques, M.Sc., Départment de biologie, Université Laval, Canada, 2015.

Bhiry, N., Delwaide, A., Allard, M., Bégin, Y., Filion, L., Lavoie, M., Nozais, C., Payette, S., Pienitz, R., Saulnier-Talbot, É., and 
Vincent, W. F.: Environmental change in the Great Whale River region, Hudson Bay: Five decades of multidisciplinary research by Centre d'études nordiques (CEN), Ecoscience, 18, 182-203, 2011.

Bonilla, S., Villeneuve, V., and Vincent W. F.: Benthic and planktonic algal communities in a high arctic lake: Pigment structure and contrasting responses to nutrient enrichment, J. Phycol., 41, 1120-1130, 2005.

Bowden, W. B., Gooseff, M. N., Balser, A., Green, A., Peterson, B. J., and Bradford, J.: Sediment and nutrient delivery from thermokarst features in the foothills of the North Slope, Alaska: Potential impacts on headwater stream ecosystems, J. Geophys. Res., 113, G02026, doi:10.1029/2007JG000470, 2008.

Bowen, H. J. M.: Environmental Chemistry of the Elements, Academic Press, London, UK, 1979.

Breton, J., Prairie, Y., Vallières, C., and Laurion, I.: Limnological properties of permafrost thaw ponds in northeastern Canada, Can. J. Fish. Aquat. Sci., 66, 1635-1648, 2009.

Burpee, B., Saros, J. E., Northington, R. M., and Simon, K. S.: Microbial nutrient limitation in Arctic lakes in a permafrost landscape of southwest Greenland, Biogeosciences, 13, 365-374, doi:10.5194/bg-13-365-2016, 2016.

Calmels, F. and Allard, M.: Ice segregation and gas distribution in permafrost using tomodensitometric analysis, Permafrost Periglac., 15, 367-378, 2004

Calmels, F., Gagnon, O., and Allard, M.: A portable earth-drill system for permafrost studies, Permafrost Periglac., 16, 311-315, 2005.

Comte, J., Lovejoy, C., Crevecoeur, S., and Vincent, W. F.: Cooccurrence patterns in aquatic bacterial communities across changing permafrost landscapes, Biogeosciences, 13, 175-190, doi:10.5194/bg-13-175-2016, 2016.

Crevecoeur, S., Vincent, W. F., Comte, J., and Lovejoy, C.: Bacterial community structure across environmental gradients in permafrost thaw ponds: methanotroph-rich ecosystems, Front. Microbiol., 6, 192, doi:10.3389/fmicb.2015.00192, 2015.

Crump, B. C., Baross, J. A., and Simenstad, C. A.: Dominance of particle-attached bacteria in the Columbia River estuary, USA, Aquat. Microb. Ecol., 14, 7-18, 1998.

Crump, B. C., Armbrust, E. V., and Baross, J. A.: Phylogenetic analysis of particle-attached and free-living bacterial communities in the Columbia River, its estuary, and the adjacent coastal ocean, Appl. Environ. Microbiol., 65, 3192-3204, 1999.

del Giorgio, P. A. and Bouvier, T. C.: Linking the physiologic and phylogenetic successions in free-living bacterial communities along an estuarine salinity gradient, Limnol. Oceanogr., 47, 471-486, 2002.

del Giorgio, P. A., Prairie, Y., and Bird, D. F.: Coupling between rates of bacterial production and the abundance of metabolically active bacteria in lakes, enumerated using CTC reduction and flow cytometry, Microb. Ecol., 34, 144-154, 1997.

Deshpande, B. N., MacIntyre, S., Matveev, A., and Vincent, W. F.: Oxygen dynamics in permafrost thaw lakes: Anaerobic bioreactors in the Canadian subarctic, Limnol. Oceanogr., 60, 16561670, 2015.

Fichot, C. G. and Benner, R.: The spectral slope coefficient of chromophoric dissolved organic matter (S275-295) as a tracer of terrigenous dissolved organic carbon in river-influenced ocean margins, Limnol. Oceanogr., 57, 1452-1466, 2012.
Fillion, M.-E., Bhiry, N., and Touazi, M. Differential development of two palsa fields in a peatland located near WhapmagoostuiKuujjuarapik, Northern Quebec, Canada, Arct. Antarct. Alp. Res., 46, 40-54, 2014.

Fletcher, M.: The physiological activity of bacteria attached to solid surfaces, Adv. Microb. Physiol., 32, 53-85, 1991.

Forsström, L., Roiha, T., and Rautio, M.: Responses of microbial food web to increased allochthonous DOM in an oligotrophic subarctic lake, Aquat. Microb. Ecol., 68, 171-184, 2013.

Galand, P. E., Lovejoy, C., Pouliot, J., and Vincent, W. F.: Heterogeneous archaeal communities in the particle-rich environment of an arctic shelf ecosystem, J. Mar. Syst., 74, 774-782, 2008.

Garneau, M.-È., Vincent, W. F., Alonso-Sáez, L., Gratton, Y., and Lovejoy, C.: Prokaryotic community structure and heterotrophic production in a river-influenced coastal arctic ecosystem, Aquat. Microb. Ecol., 42, 27-40, 2006.

Ghiglione, J. F., Mevel, G., Pujo-Pay, M., Mousseau, L., Lebaron, P., and Goutx, M.: Diel and seasonal variations in abundance, activity, and community structure of particle-attached and freeliving bacteria in NW Mediterranean Sea, Microb. Ecol., 54, 217-231, 2007.

Gorham, E. and Janssens, J. A.: The distribution and accumulation of chemical elements in five peat cores from the mid-continent to the eastern coast of North America, Wetlands, 25, 259-278, 2005.

Gorham, E., Lehman, C., Dyke, A., Clymo, D., and Janssens, J., Long-term carbon sequestration in North American peatlands, Quat. Sci. Rev., 58, 77-82, 2012.

Grossart, H. P. and Simon, M.: Limnetic macroscopic organic aggregates (lake snow): Occurrence, characteristics, and microbial dynamics in Lake Constance, Limnol. Oceanogr., 38, 532-546, 1993.

Höfle, S., Rethemeyer, J., Mueller, C. W., and John, S.: Organic matter composition and stabilization in a polygonal tundra soil of the Lena-Delta, Biogeosciences, 10, 3145-3158, doi:10.5194/bg-10-3145-2013, 2013.

Iriberri, J., Unanue, M., Ayo, B., Barcina, I., and Egea, L.: Bacterial production and growth rate estimation from $[3 \mathrm{H}]$ thymidine incorporation for attached and free-living bacteria in aquatic systems, Appl. Environ. Microbiol., 56, 483-487, 1990.

Judd, K. E., Crump, B. C., and Kling, G. W.: Variation in dissolved organic matter controls bacterial production and community composition, Ecology, 87, 2068-2079, 2006.

Kankaala, P., Huotari, J., Peltomaa, E., Saloranta, T., and Ojala, A. Methanotrophic activity in relation to methane efflux and total heterotrophic bacterial production in a stratified, humic, boreal lake, Limnol. Oceanogr., 51, 1195-1204, 2006.

Karlsson, J., Jonsson, A., and Jansson, M.: Bacterioplankton production in lakes along an altitude gradient in the subarctic north of Sweden, Microb. Ecol., 42, 372-382, doi:10.1007/s00248001-0009-9, 2001.

Kirchman, D.: Measuring bacterial biomass production and growth rates from leucine incorporation in natural aquatic environments, Methods Microbiol., 30, 227-237, 2001.

Kirchman, D. and Mitchell, R.: Contribution of particle-bound bacteria to total microheterotrophic activity in five ponds and two marshes, Appl. Environ. Microbiol., 43, 200-209, 1982.

Kirchman, D. L. and Ducklow, H. W.: Trophic dynamics of particlebound bacteria in pelagic ecosystems: a review, in: Detritus and 
Microbial Ecology in Aquaculture, edited by: Moriaty, D. J. W. and Pullin, R. S. V., ICLARM Conference Proceedings 14, International Center for Living Aquatic Resources Management, Manila, Philippines, 54-82, 1987.

Kirchman, D. L., Keel, R. G., Simon, M., and Welschmeyer, N. A.: Biomass and production of heterotrophic bacterioplankton in the oceanic subarctic Pacific, Deep-Sea Res. Pt. 1, 40, 967-988, 1993.

Kirøboe, T.: Formation and fate of marine snow: small-scale processes with large-scale implications, Sci. Mar, 65, 57-71, 2001.

Kling, G. W., Kipphut, G. W., and Miller, M. C.: Arctic lakes and streams as gas conduits to the atmosphere: Implications for tundra carbon budgets, Science, 251, 298-301, 1991.

Lami, R., Cuperoa, Z., Ras, J., Lebaron, P., and Koblízek, M.: Distribution of free-living and particle-attached aerobic anoxygenic phototrophic bacteria in marine environments, Aquat. Microb. Ecol., 55, 31-38, 2009.

Lapierre, J. F., Guillemette, F., Berggren, M., and del Giorgio, P. A.: Increases in terrestrially derived carbon stimulate organic carbon processing and $\mathrm{CO}_{2}$ emissions in boreal aquatic ecosystems, Nat. Commun., 4, 2927, doi:10.1038/ncomms3972, 2013.

Laurion, I., Vincent, W. F., Retamal, L., Dupont, C., Francus, P., MacIntyre, S., and Pienitz, R.: Variability in greenhouse gas emissions from permafrost thaw ponds, Limnol. Oceanogr., 55, 115-133, 2010.

Liebner, S., Ganzert, L., Kiss, A., Yang, S., Wagner, D., and Svenning, M. M.: Shifts in methanogenic community composition and methane fluxes along the degradation of discontinuous permafrost, Front. Microbiol., 6, 356, doi:10.3389/fmicb.2015.00356, 2015.

Lymer, D., Lindström, E. S., and Vrede, K.: Variable importance of viral-induced bacterial mortality along gradients of trophic status and humic content in lakes, Freshwater Biol., 53, 1101-1113, 2008

Mann, P. J., Sobczak, W. V., Larue, M. M., Bulygina, E., Davydova, A., Vonk, J. E., Schade, J., Davydoc, S., Zimov, N., Holmes, R. M., and Spencer, R. G. M.: Evidence for key enzymatic controls on metabolism of Arctic river organic matter, Glob. Change Biol., 20, 1089-1100, 2014.

Masin, M., Uperova, Z. C., Hojerova, E., Salka, I., Grossart, H.P., and Koblizek, M.: Distribution of aerobic anoxygenic phototrophic bacteria in glacial lakes of northern Europe, Aquat. Microb. Ecol., 66, 77-86, 2012.

Matveev, A., Laurion, I., Deshpande, B. N., Bhiry, N., and Vincent, W. F.: High methane emissions from thermokarst lakes in subarctic peatlands, Limnol. Oceanogr., 61, doi:10.1002/lno.10311, 2016.

McClelland, J. W., Stieglitz, M., Pan, F., Holmes, R. M., and Peterson, B. J.: Recent changes in nitrate and dissolved organic carbon export from the upper Kuparuk River, North Slope, Alaska, J. Geophys. Res., 112, G04S60, doi:10.1029/2006JG000371, 2007.

Michaels, A. F. and Silver, M. W.: Primary production, sinking fluxes and the microbial food web, Deep-Sea Res. Pt. 1, 35, 473490, 1988

Moquin, P. A. and Wrona, F. J.: Effects of permafrost degradation on water and sediment quality and heterotrophic bacterial production of Arctic tundra lakes: An experimental approach, Limnol. Oceanogr., 60, 1484-1497, 2015.
Pace, M. L. and Cole, J. J.: Comparative and experimental approaches to top-down and bottom-up regulation of bacteria, Microb. Ecol., 28, 181-193, 1994.

Ploug, H. and Grossart, H. P.: Bacterial growth and grazing on diatom aggregates: Respiratory carbon turnover as a function of aggregate size and sinking velocity, Limnol. Oceanogr., 45, 14671475, 2000.

Przytulska, A., Bartosiewicz, M., Rautio, M., Dufresne, F., and Vincent, W. F.: Climate effects on Arctic Daphnia via food quality and thresholds, PLoS ONE, 10, e0126231, doi:10.1371/journal.pone.0126231, 2015.

Przytulska, A., Comte, J., Crevecoeur, S., Lovejoy, C., Laurion, I., and Vincent, W. F.: Phototrophic pigment diversity and picophytoplankton in permafrost thaw lakes, Biogeosciences, 13, 13-26, doi:10.5194/bg-13-13-2016, 2016.

Pulido-Villena, E. and Reche, I.: Exploring bacterioplankton growth and protein synthesis to determine conversion factors across a gradient of dissolved organic matter, Microb. Ecol., 46, 33-42, 2003.

Rautio, M. and Vincent, W. F.: Benthic and pelagic food resources for zooplankton in shallow high-latitude lakes and ponds, Freshwater Biol., 51, 1038-1052, 2006.

Roehm, C. L., Giesler, R., and Karlsson, J.: Bioavailability of terrestrial organic carbon to lake bacteria: The case of a degrading subarctic permafrost mire complex, J. Geophys. Res., 114, G03006, doi:10.1029/2008JG000863, 2009.

Roiha, T., Tiirola, M., Cazzanelli, M., and Rautio, M.: Carbon quantity defines productivity while its quality defines community composition of bacterioplankton in subarctic ponds, Aquat. Sci., 74, 513-525, 2012.

Roiha, T., Laurion, I., and Rautio, M.: Carbon dynamics in highly heterotrophic subarctic thaw ponds, Biogeosciences, 12, 72237237, doi:10.5194/bg-12-7223-2015, 2015.

Simon, M. and Azam, F.: Protein content and protein synthesis rates of planktonic marine bacteria, Mar. Ecol. Prog. Ser, 51, 201-213, 1989.

Simon, M. and Kirchman, D.: Isotope dilution during bacterial amino acid uptake in the subarctic Pacific: evidence for ammonium utilization by bacteria, EOS, 69, 1146 , doi:10.1002/lno.10311, 1988.

Simon, M., Alldredge, A. L., and Azam, F.: Bacterial carbon dynamics on marine snow, Mar. Ecol. Prog. Ser., 65, 205-211, 1990.

Smith, D. C. and Azam, F.: A simple, economical method for measuring bacterial protein synthesis rates in seawater using $3 \mathrm{H}-$ leucine, Mar. Microb. Food Webs, 6, 107-114, 1992.

Smith, E. M. and Prairie, Y. T.: Bacterial metabolism and growth efficiency in lakes: The importance of phosphorus availability, Limnol. Oceanogr., 49, 137-147, 2004.

Tarnocai, C., Canadell, J. G., Schuur, E. A. G., Kuhry, P., Mazhitova, G., and Zimov, S.: Soil organic carbon pools in the northern circumpolar permafrost region, Global Biogeochem. Cy., 23, GB2023, doi:10.1029/2008GB003327, 2009.

Tulonen, T., Kankaala, P., Ojala, A., and Arvola, L.: Factors controlling production of phytoplankton and bacterial under ice in a humic, boreal lake, J. Plankton Res., 16, 1411-1432, 1994.

Unanue, M., Ayo, B., Azúa, I., Barcina, I., and Iriberri, J.: Temporal variability of attached and free-living bacteria in coastal waters, Microb. Ecol., 23, 27-39, 1992. 
Vallières, C., Retamal, L., Ramlal, P., Osburn, C. L., and Vincent, W. F.: Bacterial production and microbial food web structure in a large arctic river and the coastal Arctic Ocean, J. Mar. Syst., 74, 756-773, 2008.

Vonk, J. E., Tank, S. E., Bowden, W. B., Laurion, I., Vincent, W. F., Alekseychik, P., Amyot, M., Billet, M. F., Canário, J., Cory, R. M., Deshpande, B. N., Helbig, M., Jammet, M., Karlsson, J., Larouche, J., MacMillan, G., Rautio, M., Walter Anthony, K. M., and Wickland, K.P.: Effects of permafrost thaw on arctic aquatic ecosystems, Biogeosciences 12, 7129-7167, doi:10.5194/bg-127129-2015, 2015.

Waidner, L. A. and Kirchman, D. L.: Aerobic anoxygenic phototrophic bacteria attached to particles in turbid waters of the Delaware and Chesapeake estuaries, Appl. Environ. Microbiol., 73, 3936-3944, 2007.
Watanabe, S., Laurion, I., Chokmani, K., Pienitz, R., and Vincent, W. F.: Optical diversity of thaw ponds in discontinuous permafrost: A model system for water color analysis, J. Geophys. Res., 116, G02003, doi:10.1029/2010jg001380, 2011.

Yoon, W. B. and Rosson, R. A.: Improved method of enumeration of attached bacteria for study of fluctuation in the abundance of attached and free-living bacteria in response to diel variation in seawater turbidity, Appl. Environ. Microbiol., 56, 595-600, 1990. 